Check for updates

Cite this: J. Mater. Chem. C, 2017, 5,6777

\section{Bright green PhOLEDs using cyclometalated diiridium(III) complexes with bridging oxamidato ligands as phosphorescent dopants $\dagger$}

\author{
Ahmed M'hamedi, ${ }^{a}$ Mark A. Fox, (D) ${ }^{\text {b }}$ Andrei S. Batsanov, ${ }^{b}$ Hameed A. Al-Attar, \\ Andrew P. Monkman ${ }^{c}$ and Martin R. Bryce iD *b
}

\begin{abstract}
In contrast to monoiridium complexes, the study of diiridium complexes as dopants in phosphorescent organic light-emitting devices (PhOLEDs) is largely unexplored. We now describe the syntheses, detailed NMR analyses, X-ray crystal structures and optoelectronic properties of the new cyclometalated diiridium complexes 5 and 6 in which the iridium centres are bridged by oxamidato ligands. These complexes contain diastereomers - the meso form $(\Delta \Lambda)$ and the racemic form consisting of two enantiomers $(\Delta \Delta$ and $\Lambda \Lambda$ ) - with anti-oxamidato bridges. The precursor $\mu$-dichloro-bridged complex $\mathbf{4}$ is very weakly emissive in solution, whereas the oxamidato bridged complexes 5 and $\mathbf{6}$ are highly emissive $\left(\Phi_{\mathrm{PL}} 73 \%\right.$ and $63 \%$ ) with short excited state lifetimes of $\tau_{\mathrm{P}} 0.84$ and $1.16 \mu \mathrm{s}$, respectively. Cyclic voltammetry studies demonstrate that the oxamidato bridging ligand plays a role in mediating intramolecular interactions between the iridium centres. Density functional theory (DFT) calculations and time dependent-DFT (TD-DFT) calculations provide further insights into the structural, electronic, and photophysical properties of the complexes in their ground and excited states. Phosphorescent organic light-emitting diodes (PhOLEDs) using complexes $\mathbf{5}$ and $\mathbf{6}$ as the emissive dopants in a simple architecture using a solution-processed active layer give bright green electroluminescence with remarkably high luminance $\left(L_{\max }>25000 \mathrm{~cd} \mathrm{~m}^{-2}\right)$ for diiridium complexes.
\end{abstract}

Received 9th February 2017, Accepted 18th June 2017

DOI: $10.1039 / c 7 t c 00628 d$

rsc.li/materials-c both singlet and triplet excited states theoretically achieves $100 \%$ internal quantum efficiency. Ir(III) complexes are synthetically versatile and they possess many favourable properties, such as high quantum efficiency $(\Phi)$, short phosphorescence lifetimes $\left(\tau_{\mathrm{p}}\right)$ and reversible electrochemistry. The metal-ligand-based luminescent properties of Ir(III) complexes enable colour tuning across a broad range of the visible spectrum through systematic structural variation of the ligands.

Cyclometalated diiridium complexes with a $\mu$-dichlorobridge ${ }^{13}$ are the standard precursors to homoleptic and heteroleptic monoiridium complexes. ${ }^{14}$ However, the $\mu$-dichloro-bridged dimers are generally very poorly emissive ${ }^{15,16}$ (although there are a few exceptions). ${ }^{17,18}$ Most other diiridium systems also have low luminescence quantum yields ${ }^{19-24}$ which has focussed the vast majority of research onto the more strongly emissive monoiridium complexes. ${ }^{1-3}$ However, the bridging ligands within diiridium complexes provide unique potential for additional structural and electronic variations compared to monoiridium systems. High efficiency phosphorescence typically results from preventing non-radiative deactivation by rigidification of the emitter framework ${ }^{25}$ which can be enhanced by judicious choice of the bridging ligand. Additionally, the presence of a second metal might introduce a larger spin-orbit coupling effect than that associated with a single metal centre. 

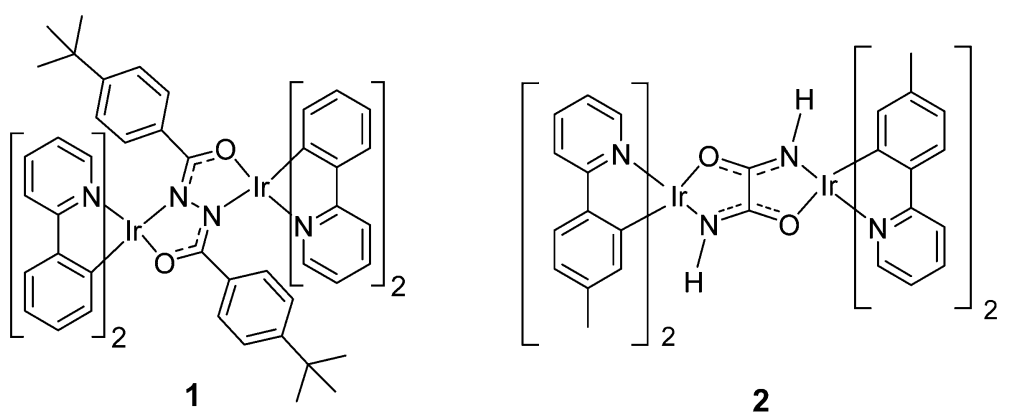

2

Fig. 1 Relevant diiridium complexes $\mathbf{1}^{34}$ and $\mathbf{2}^{32}$ reported previously.

A few diiridium complexes, especially those with conjugated bridging ligands, are known to possess efficient photoluminescence $\left(\Phi_{\mathrm{PL}}\right.$ typically $\sim 30-60 \%$ in solution). ${ }^{26-32}$ There are even examples of solution photoluminescence quantum yields (PLQYs) up to $100 \%$ for diiridium complexes with a bis- $\mathrm{N}^{\wedge} \mathrm{C}^{-}$ coordinating diarylpyrimidinyl bridging ligand. ${ }^{33}$ The use of diiridium complexes as dopants in phosphorescent organic light-emitting devices (PhOLEDs) is largely unexplored. However, solution-processed PhOLEDs with external quantum efficiencies (EQEs) of $>10 \%$ have recently been fabricated by our group (complex 1, Fig. 1) ${ }^{34}$ and by Yang et al., using a 2-(4-tertbutylphenyl)pyrimidine bridging ligand. ${ }^{35} \mathrm{~A}$ few other examples of neutral diiridium PhOLEDs with lower efficiencies and low brightnesses have also been reported. ${ }^{36}$ A low-efficiency PhOLED using a cationic diiridium emitter has also been demonstrated. ${ }^{37}$ Therefore, it is important to explore diiridium systems in the search for new families of OLED materials.

The motivation for the present work is to develop the optoelectronic properties and PhOLED applications of diiridium complexes with bridging oxamidato ligands, noting that their $\mathrm{C}_{2} \mathrm{~N}_{2} \mathrm{O}_{2}$ structure is isomeric with the diarylhydrazido bridge of our previous complex $1 .^{34}$ We reasoned that the rigidity of the bis-coordinated oxamidato ligands could lead to high photoand electro-luminescence quantum yields. Indeed, Sünkel and co-workers recently showed that complex 2 is a green emitter with $\Phi_{\mathrm{PL}} 60 \%$ in degassed dichloromethane solution, although no OLEDs were reported in that work. ${ }^{32}$ We have now synthesised complexes 5 and $\mathbf{6}$ and discuss their single-crystal X-ray structures, NMR spectra, electrochemical and photophysical properties. Notably, complex 6 is the first reported example with any substituent (other than hydrogens) on the oxamidato bridge. Density functional theory (DFT) and time dependent DFT (TD-DFT) calculations provide further insights into the structural, electronic, and photophysical properties in the ground and excited states. Phosphorescent organic light-emitting diodes (PhOLEDs) using complex 5 or $\mathbf{6}$ as the emissive dopant in a solution-processed active layer give bright electroluminescence with luminance values as high as $>25000 \mathrm{~cd} \mathrm{~m}^{-2}$. The present work, therefore, represents the first thorough investigation of the properties of diiridium complexes with bridging oxamidato ligands, including new structural modifications. To our knowledge these data strongly compete with the brightest reported PhOLEDs using bimetallic complexes as the emitter. ${ }^{34,35}$

\section{Results and discussion}

The synthesis of the diiridium complexes is shown in Scheme 1. Ligand 3 and the derived complexes 4-6 incorporate a mesityl substituent at $\mathrm{C} 4$ of each of the ppy ligands as there is precedent that a mesityl group at this position significantly improves the solubility of iridium complexes in organic solvents thereby facilitating device fabrication by solution processing, while having minimal effect on the emission colour. ${ }^{38-43}$ The $\mu$-dichloro-bridged species $4^{43}$ was obtained in $66 \%$ yield using the standard procedure ${ }^{44}$ by reacting 3 with $\operatorname{IrCl}_{3} \cdot 3 \mathrm{H}_{2} \mathrm{O}$ in 2-ethoxyethanol. Reaction of 4 with oxamide or with $N, N^{\prime}$-di-tbutylphenyloxamide in the presence of sodium methoxide gave

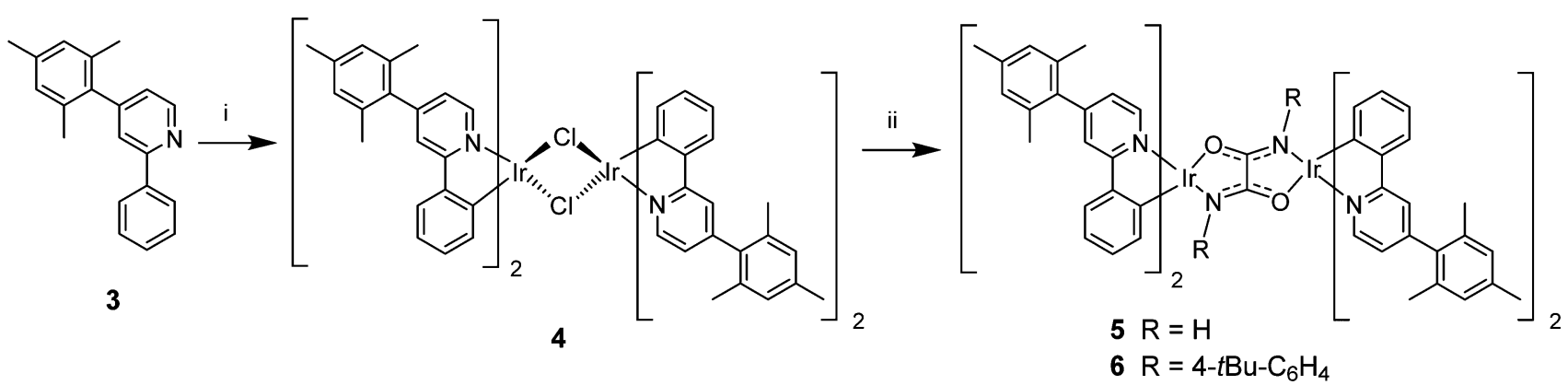

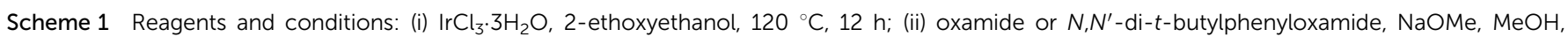
$20{ }^{\circ} \mathrm{C}, 24 \mathrm{~h}$. 
the target oxamido-bridged complexes $\mathbf{5}$ and $\mathbf{6}$ as yellow-orange solids in $c a$. $60 \%$ yields after purification by column chromatography and recrystallisation.

The structures of the dinuclear complexes were confirmed by MALDI mass spectra (Fig. S6, S7 in ESI $\dagger$ ), elemental analysis and $\mathrm{X}$-ray crystallography (for 5 and 6). The ${ }^{1} \mathrm{H}$ and ${ }^{13} \mathrm{C}$ NMR spectra of 5 and $\mathbf{6}$ (see the ESI $\dagger$ ) exhibit many peaks, as noted previously for other diiridium complexes, ${ }^{31}$ due to the presence of isomers the meso form $(\Delta \Lambda)$ and the racemic form consisting of two enantiomers $(\Delta \Delta$ and $\Lambda \Lambda)$. Furthermore, as noted by Sünkel for complex $2,{ }^{32}$ both the syn- and anti-oxamidato bridge structures are feasible, although the anti geometry with $\mathrm{N}^{\wedge} \mathrm{O}$ coordination at each iridium centre appears more reasonable, as observed unambiguously in the crystal structure of complex 6 (see below) and favoured in the crystal structure of $\mathbf{5}$. It is well known to be often very laborious, and sometimes not possible, to isolate the isomers of diiridium complexes in their pure form. ${ }^{33,45}$ We were unable to separate the isomers of 5 or $\mathbf{6}$ by recrystallisation or chromatography, including HPLC.

Table 1 lists all ${ }^{13} \mathrm{C}$ NMR peak assignments corresponding to the ppy ligands for complexes 4-6. NMR data for complex 2 assigned elsewhere ${ }^{32}$ where two stereoisomers were observed in a 3:1 ratio, are also listed. The peaks for 4, 5 and 6 were assigned here with the aid of $2 \mathrm{D}{ }^{1} \mathrm{H}-{ }^{1} \mathrm{H}$ COSY and ${ }^{1} \mathrm{H}^{-13} \mathrm{C}$ correlation (HSQC and HMBC) NMR spectra. The dichlorobridged complex 4 has only the racemic form $(\Delta \Delta$ and $\Lambda \Lambda)$ due to steric effects preventing the formation of the meso form $(\Delta \Lambda)$ and the higher symmetry of the dichloro-bridge results in one set of ${ }^{13} \mathrm{C}$ NMR peaks for a ppy ligand observed here.

The NMR data for complexes 5 and $\mathbf{6}$ indicate the presence of two isomers - the meso form $(\Delta \Lambda)$ and the racemic form
$(\Delta \Delta$ and $\Lambda \Lambda$ ). A $3: 2$ ratio of isomers is observed in both cases but it is unfortunately not possible to assign one form to one set of NMR data corresponding to the major isomer. Similarly, the NMR data for 2 could not be assigned to the isomers, but Sünkel assumed the anti geometry with $\mathrm{N}^{\wedge} \mathrm{O}$ coordination at each iridium centre for both isomers. ${ }^{32}$ The proposed anti geometries are indeed supported by X-ray data here. The remarkable similarities between the ${ }^{13} \mathrm{C}$ NMR data for 2 and for 5 with the largest shift differences of 9-10 ppm found for the carbon atom attached to iridium (C12) (Fig. 2) confirm that complexes 2 and 5 contain mixtures of meso $(\Delta \Lambda)$ and racemic ( $\Delta \Delta$ and $\Lambda \Lambda$ ) anti geometries. The effect of the tert-butylphenyl groups at the nitrogens of the bridge in complex 6 on the ${ }^{13} \mathrm{C}$ NMR shifts compared to those for 5 is obvious with shift differences of over $1 \mathrm{ppm}$ for seven carbons (C2, C3, C6, C7, C9, C11, C12) of the ppy ligands in 6 compared to only two (C6, C12) in 5. Interestingly, the shift differences for C12 in 6 are about half the corresponding values for $\mathbf{2}$ and $\mathbf{5}$.

The thermal stabilities of the diiridium complexes 4-6 were evaluated using thermal gravimetric analysis (TGA) and differential scanning calorimetry (DSC) under a nitrogen atmosphere. The $5 \%$ weight loss temperatures $\left(T_{\mathrm{d}}\right)$ are $>370{ }^{\circ} \mathrm{C}$ for all complexes, suggesting the complexes should be thermally stable under the conditions of device operation. TGA and DSC traces for 5 and 6 are shown in Fig. S8-S11, ESI. $\dagger$

Single crystal X-ray structures (Fig. 3, Table 2 and Fig. S1-S3, $\mathrm{ESI} \dagger$ ) were obtained for $\mathbf{5}$-hexane and 6.pentane. $\mathrm{PhCl}$ solvates, grown from mixtures of stereoisomers in solution. Molecule $\mathbf{5}$ lies on a crystallographic two-fold axis which is perpendicular to the bridge plane. As noted by Sünkel et al. for complex 2, the $\mathrm{N}(\mathrm{H})$ and $\mathrm{O}$ atoms are statistically mixed, hence the stereochemistry

Table $1{ }^{13} \mathrm{C}\left\{{ }^{1} \mathrm{H}\right\}$ NMR chemical shifts (ppm) for $2,{ }^{32} \mathbf{4}, \mathbf{5}$ and $\mathbf{6}$. Diastereomer ratios are $3: 1$ for $\mathbf{2}$ and $3: 2$ for $\mathbf{5}$ and $\mathbf{6}$

\begin{tabular}{|c|c|c|c|c|c|c|c|c|c|c|c|}
\hline & $\mathrm{C} 2$ & C3 & $\mathrm{C} 4$ & C5 & C6 & C7 & $\mathrm{C} 8$ & C9 & C10 & C11 & C12 \\
\hline \multicolumn{12}{|l|}{2} \\
\hline Major & 169.25 & 118.63 & 137.34 & 121.50 & 149.55 & 142.23 & 124.28 & 122.12 & 139.80 & 133.99 & 155.07 \\
\hline Isomer & 168.72 & 118.43 & 136.47 & 121.44 & 148.34 & 142.20 & 124.18 & 121.84 & 139.50 & 133.36 & 145.73 \\
\hline Difference & 0.53 & 0.20 & 0.87 & 0.06 & 1.21 & 0.03 & 0.10 & 0.28 & 0.30 & 0.63 & 9.34 \\
\hline Minor & 169.17 & 118.54 & 137.16 & 121.50 & 149.81 & 142.26 & 124.22 & 122.05 & 139.74 & 133.99 & 155.11 \\
\hline Isomer & 168.65 & 118.35 & 136.32 & 121.44 & 148.34 & 142.20 & 124.11 & 121.79 & 139.50 & 133.36 & 145.70 \\
\hline Difference & 0.52 & 0.19 & 0.84 & 0.06 & 1.47 & 0.06 & 0.11 & 0.26 & 0.24 & 0.63 & 9.41 \\
\hline \multicolumn{12}{|l|}{4} \\
\hline & 168.49 & 120.41 & 150.80 & 123.44 & 151.58 & 144.11 & 123.71 & 121.42 & 129.32 & 130.03 & 144.50 \\
\hline \multicolumn{12}{|l|}{5} \\
\hline Major & 169.23 & 119.86 & 150.58 & 122.41 & 149.02 & 144.32 & 124.26 & 120.69 & 129.54 & 132.52 & 154.78 \\
\hline Isomer & 168.98 & 119.42 & 149.88 & 122.38 & 147.76 & 144.30 & 123.87 & 120.36 & 129.34 & 132.11 & 144.78 \\
\hline Difference & 0.25 & 0.44 & 0.70 & 0.03 & 1.26 & 0.02 & 0.39 & 0.33 & 0.20 & 0.41 & 10.00 \\
\hline Minor & 169.20 & 119.76 & 150.48 & 122.51 & 149.23 & 144.35 & 124.29 & 120.72 & 129.50 & 132.66 & 154.71 \\
\hline Isomer & 168.91 & 119.45 & 149.72 & 122.50 & 147.65 & 144.25 & 123.85 & 120.38 & 129.39 & 132.24 & 144.78 \\
\hline Difference & 0.29 & 0.31 & 0.76 & 0.01 & 1.58 & 0.10 & 0.44 & 0.34 & 0.11 & 0.42 & 9.93 \\
\hline \multicolumn{12}{|l|}{6} \\
\hline Major & 169.43 & 120.47 & 150.77 & 122.88 & 149.35 & 145.05 & 124.31 & 120.91 & 129.13 & 133.24 & 152.88 \\
\hline Isomer & 168.39 & 119.31 & 150.52 & 122.20 & 147.50 & 143.47 & 123.52 & 119.73 & 128.86 & 131.75 & 148.45 \\
\hline Difference & 1.04 & 1.16 & 0.25 & 0.68 & 1.85 & 1.58 & 0.79 & 1.18 & 0.27 & 1.49 & 4.43 \\
\hline Minor & 169.45 & 120.19 & 150.77 & 122.83 & 149.23 & 145.00 & 124.26 & 120.78 & 129.23 & 133.09 & 152.96 \\
\hline Isomer & 168.21 & 119.19 & 150.27 & 122.30 & 147.63 & 143.43 & 123.40 & 119.71 & 128.88 & 132.05 & 148.64 \\
\hline Difference & 1.24 & 1.00 & 0.50 & 0.53 & 1.60 & 1.57 & 0.86 & 1.07 & 0.35 & 1.04 & 4.32 \\
\hline
\end{tabular}




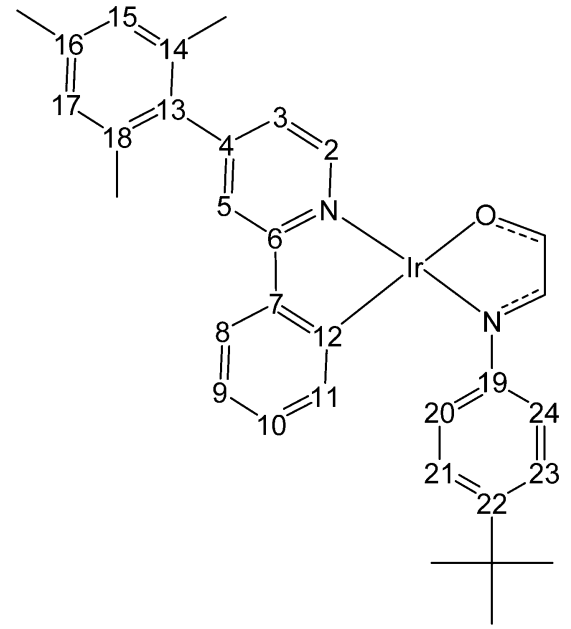

Fig. 2 Carbon atom numbering used in the NMR peak assignments of 6 in Table 1. This numbering also applies to NMR data of diiridium complexes $\mathbf{2}$, 4 and 5.
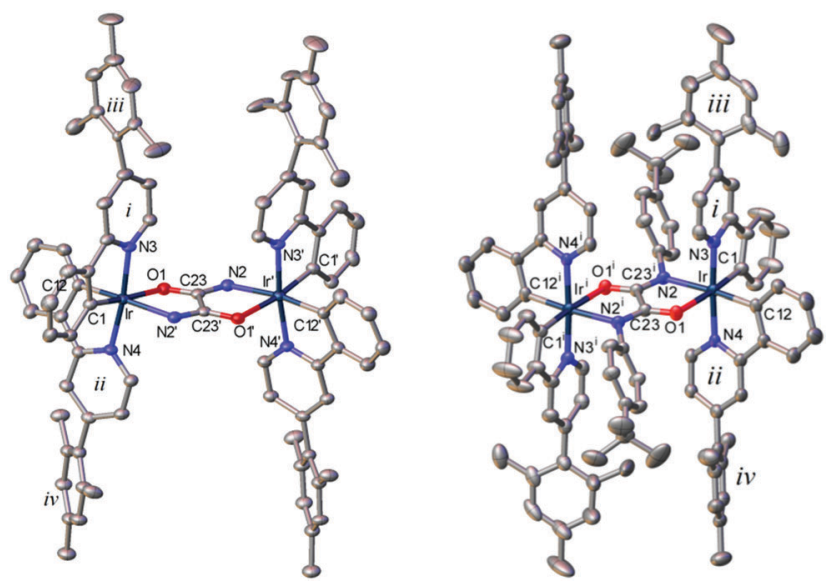

Fig. 3 X-ray molecular structures of $\mathbf{5}$ (major component) and $\mathbf{6}$. Displacement ellipsoids are drawn at 50\% probability level. $\mathrm{H}$ atoms, disorder and solvent of crystallisation are omitted for clarity. Primed atoms are generated by twofold axis (5) or inversion centre (6).

Table 2 Selected bond distances in $\AA$ for $\mathbf{2}^{32} \mathbf{5}$ and $\mathbf{6}$

\begin{tabular}{llll}
\hline & $\mathbf{2}$ & $\mathbf{5}$ & $\mathbf{6}$ \\
\hline $\mathrm{Ir}-\mathrm{O}(1)$ & $2.20(2)^{a}$ & $2.194(13)^{a}$ & $2.184(3)$ \\
$\mathrm{Ir}-\mathrm{N}(1)$ & $2.18(2)^{a}$ & $2.13(2)^{a}$ & \\
$\mathrm{Ir}-\mathrm{N}(2)$ & $2.132(15)^{a}$ & $2.135(18)^{a}$ & $2.147(3)$ \\
$\mathrm{Ir}-\mathrm{O}(2)$ & $2.180(15)^{a}$ & $2.19(2)^{a}$ & \\
$\mathrm{Ir}-\mathrm{N}(3)$ & $2.030(5)$ & $2.042(3)$ & $2.023(4)$ \\
$\mathrm{Ir}-\mathrm{N}(4)$ & $2.029(5)$ & $2.032(3)$ & $2.040(4)$ \\
$\mathrm{Ir}-\mathrm{C}(1)$ & $1.993(5)$ & $1.993(4)$ & $1.982(4)$ \\
$\mathrm{Ir}-\mathrm{C}(12)$ & $2.008(6)$ & $2.013(3)$ & $2.013(4)$ \\
$\mathrm{Ir} \cdots \mathrm{Ir}^{\prime}$ & 5.718 & 5.688 & 5.726 \\
${ }^{a} \mathrm{~N} / \mathrm{O}$ disorder in the bridge. & & \\
\end{tabular}

of the bridge cannot be established unequivocally; however, for 5 the observed electron density is best fit by an overlap of two alternative anti-configurations, with contributions of $0.64(3)[\mathrm{N}$ trans to $\mathrm{C}(12)]$ and $0.36(3)$ [N trans to $\mathrm{C}(1)]$. A similar (but $0.5: 0.5$ ) disorder has been observed in $2 .{ }^{32}$ Molecule 6 is the meso $(\Delta \Lambda)$ diastereomer, possessing crystallographic inversion symmetry. In both complexes, Ir atoms have distorted octahedral coordination with the pyridine $\mathrm{N}$ atoms trans to each other. The planarity of the $\operatorname{Ir}\left(\mathrm{O}_{2} \mathrm{C}_{2} \mathrm{~N}_{2}\right) \operatorname{Ir}$ system in $\mathbf{5}$ is distorted by a small $\left(4.7^{\circ}\right)$ twist around the $\mathrm{C}(23)-\mathrm{C}\left(23^{\prime}\right)$ bond. In 6 the $\mathrm{O}_{2} \mathrm{C}_{2} \mathrm{~N}_{2}$ moiety is planar, the Ir atoms are tilted to opposite sides of its plane by $0.14 \AA$ and the mean axes of the tolyl substituents by $19.4^{\circ}$, the bridging $\mathrm{N}(2)$ atom is planartrigonal (sum of bond angles $358.7^{\circ}$ ). The anti geometry with $\mathrm{N}^{\wedge} \mathrm{O}$ coordination at each iridium centre is observed unambiguously for the first time in the crystal structure of complex 6 .

All chelating phenylpyridine systems are slightly folded, with $\mathrm{ph} / \mathrm{py}$ interplanar angles in $\mathbf{5}\left(10.9\right.$ and $\left.12.5^{\circ}\right)$ larger than in $6\left(3.1\right.$ and $\left.6.0^{\circ}\right)$. The twists between pyridine rings and their mesityl substituents are much larger. This is expected due to steric effects involving the ortho-methyl substituents in the mesityl groups. These ortho-methyl groups in each mesityl group are non-equivalent in solution based on the observed solution-state NMR data of $\mathbf{4 , 5}$ and $\mathbf{6}$ here. In $\mathbf{5}$, the mesityl group iv is twisted to the pyridine ring ii by $45.0^{\circ}$, whereas mesityl iii is disordered, in the ratio of $0.726(9)$ to $0.274(9)$, between two orientations inclined to pyridine ring i by $77.9^{\circ}$ and $84.9^{\circ}$, respectively. In 6 , the $\mathrm{i} /$ iii and ii/iv twists are $71.8^{\circ}$ and $61.8^{\circ}$, respectively.

The redox properties of the diiridium complexes 4-6 were studied by cyclic voltammetry (CV) in dichloromethane (DCM) solution at $298 \mathrm{~K}$ (Fig. 4) and the data are tabulated along with those reported for $\mathbf{1}^{34}$ and $\left[\operatorname{Ir}(\mathrm{ppy})_{2} \mathrm{Cl}\right]_{2}{ }^{17}$ for comparison in Table 3. CV data were not reported for complex 2 for comparison. ${ }^{32}$ All complexes display two quasi-reversible, one-electron oxidation waves which are assigned to sequential oxidation of the metal centred $\mathrm{Ir}^{3+} / \mathrm{Ir}^{4+}$ redox couples. The half-wave oxidation potentials for $\mathbf{4}$ are similar to that of $\left[\operatorname{Ir}(\mathrm{ppy})_{2} \mathrm{Cl}\right]_{2}{ }^{17}$ as expected. The iridium atoms in $\mathbf{5}$ and $\mathbf{6}$ with first half-wave oxidation potentials of +0.38 to $+0.40 \mathrm{~V}$ are more easily oxidised than for 4 at $+0.56 \mathrm{~V}$

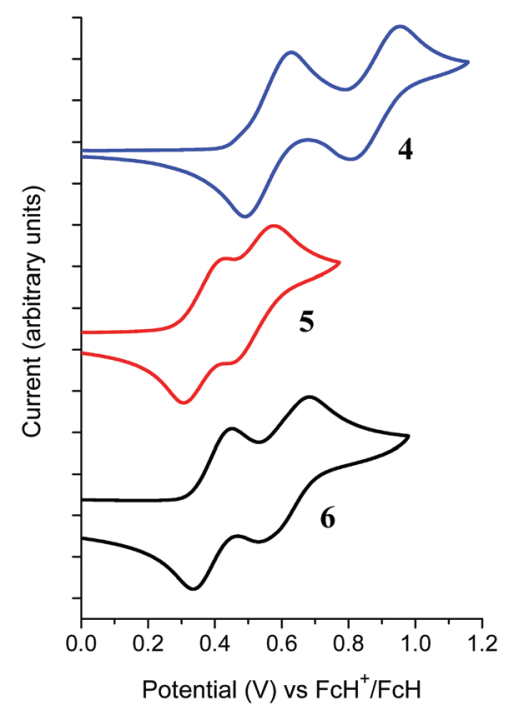

Fig. 4 Cyclic voltammetry traces for 4, 5 and 6 . 
Table 3 The half-wave oxidation potentials for the $\mathrm{Ir}^{\mathrm{III} /} / \mathrm{Ir}^{\mathrm{IV}}$ couple $\left(E_{1 / 2}^{\mathrm{ox}}, \mathrm{V}\right)$ and computed HOMO energies for the complexes, $\mathbf{1}^{34} \mathbf{4}-\mathbf{6}$ and $\operatorname{Ir}(\mathrm{ppy}){ }_{2} \mathrm{Cl}_{2}{ }^{17}$

\begin{tabular}{llllll}
\hline Complex & $E_{1 / 2}^{\text {ox }(1) a}(\mathrm{~V})$ & $E_{1 / 2}^{\text {ox }(2) a}(\mathrm{~V})$ & $\Delta E^{a}(\mathrm{mV})$ & Ir $\cdots$ Ir distance $(\AA)$ & $\mathrm{HOMO}^{b}(\mathrm{eV})$ \\
\hline $\mathbf{1}$ & +0.22 & +0.63 & 410 & 5.061 & -5.02 \\
$\mathbf{4}$ & +0.56 & +0.88 & 320 & 3.812 & -5.36 \\
$\mathbf{5}$ & +0.38 & +0.54 & 160 & 5.688 & -4.59 \\
$\mathbf{6}$ & +0.40 & +0.62 & 220 & 5.726 & -4.91 \\
$\operatorname{Ir}(\text { ppy })_{2} \mathrm{Cl}_{2}$ & +0.53 & +0.79 & 260 & 3.771 & -4.79 \\
\end{tabular}

${ }^{a} 0.1 \mathrm{M}\left({ }^{n} \mathrm{Bu}_{4} \mathrm{NPF}_{6}\right)$ in DCM at $298 \mathrm{~K}$, scan rate $100 \mathrm{mV} \mathrm{s}^{-1}$, referenced to the internal decamethylferrocene/decamethylferrocenium couple (Fc* ${ }^{*} \mathrm{Me} /$ $\left.\mathrm{Fc}^{*} \mathrm{Me}^{+}\right)$at $-0.55 \mathrm{~V}$ with the ferrocenium/ferrocene $\left(\mathrm{FcH} / \mathrm{FcH}^{+}\right)$couple as reference at $0.00 \mathrm{~V} .{ }^{b} \mathrm{HOMO}$ levels calculated from $\mathrm{CV}$ potentials by $\mathrm{HOMO}=-4.8+\left(-E_{1 / 2}^{\mathrm{ox}}\right)$, using ferrocene as the standard. ${ }^{c}$ HOMO energies calculated from optimised geometries at B3LYP/LANL2DZ:3-21G*

due to the stronger electron-withdrawing effect of the oxamidato bridge in 5 and $\mathbf{6}$ compared to the $\mu$-dichloro bridge in $\mathbf{4}$. The two isomers of compound 1 have peak separations of $400-410 \mathrm{mV}$ where the bridge plays a significant role in the photophysical properties of $1 .^{34}$ Although complexes 1, 5 and 6 have similar Ir - Ir intramolecular distances, the peak separations observed for $\mathbf{5}$ and $\mathbf{6}$ are smaller than for $\mathbf{1}$ and suggest that oxamidato bridges play a minor role with respect to their photophysical properties. The larger peak separation $(\Delta E)$ of $220 \mathrm{mV}$ between the two waves of 6 compared to $\Delta E 160 \mathrm{mV}$ for 5 suggests the monocation species is more stable for $\mathbf{6}$ than for 5. This is consistent with more HOMO character on the bridge of $\mathbf{6}$ compared to 5 (see below). The tert-butylphenyl groups at the bridge must contribute to the increased stability of the monocation from 6 with respect to the monocation from $\mathbf{5}$.

The photophysical data for 4-6 are listed in Table 4, with data for $\left[\operatorname{Ir}(\mathrm{ppy})_{3}\right]$ included for comparison. The absorption spectral profiles of 4-6 in 2-methylTHF are very similar (Fig. 5a). The high energy peaks are assigned to characteristic ligandcentred (LC) spin-allowed $\pi \rightarrow \pi^{*}$ transitions. ${ }^{46}$ At longer wavelengths the complexes exhibit a series of weaker peaks between 350 and $520 \mathrm{~nm}$ which are attributed to singlet and triplet mixed metal-to-ligand charge transfer states $\left({ }^{1} \mathrm{MLCT}\right.$ and $\left.{ }^{3} \mathrm{MLCT}\right)$ with the lowest energy band at $492 \mathrm{~nm}$ for $\mathbf{4}$, and $500 \mathrm{~nm}$ for 5 and 6 assigned to the spin-forbidden triplet ${ }^{3}$ MLCT absorption. ${ }^{46,47}$ The PL spectra of 4 and 5 show well-defined peaks at $\lambda_{\max } 518$ and $529 \mathrm{~nm}$, respectively, and like $\operatorname{Ir}(\mathrm{ppy})_{3},{ }^{48}$ are broad and featureless which indicates a dominant ${ }^{3}$ MLCT contribution and negligible signature of a ligand centred triplet $\left({ }^{3} \mathrm{LC}\right)$ contribution. The PL emission of 6 at $\lambda_{\max } 522 \mathrm{~nm}$ also has a lower

Table 4 Photophysical data of 4-6 compared with the reference complex $\operatorname{Ir}(\mathrm{ppy})_{3}{ }^{49}$

\begin{tabular}{|c|c|c|c|c|}
\hline Complex & $\lambda_{\max }^{\mathrm{Abs} a} / \mathrm{nm}$ & $\lambda_{\max }^{\mathrm{PL} b} / \mathrm{nm}$ & $\operatorname{PLQY}^{c} \Phi_{\mathrm{PL}} / \%$ & $\tau_{\mathrm{p}}^{d} / \mu \mathrm{s}$ \\
\hline 4 & $341,360,410,463,492$ & 518 & 5.6 & N/A \\
\hline 5 & $315,350,415,470,500$ & 529 & 73 & 0.84 \\
\hline 6 & $315,350,415,470,500$ & 522 & 63 & 1.164 \\
\hline $\operatorname{Ir}(\mathrm{ppy})_{3}$ & & 510 & 97 & 1.4 \\
\hline
\end{tabular}

${ }^{a}$ Data obtained in $<10 \mu \mathrm{M}$ 2-methylTHF solutions at $20{ }^{\circ} \mathrm{C} .{ }^{b}$ Data obtained in degassed 2-methylTHF solution with excitation wavelength $340 \mathrm{~nm} .{ }^{c}$ Measured relative to $\operatorname{Ir}(\mathrm{ppy})_{3} \Phi_{\mathrm{PL}}=0.97$ (ref. 49) in degassed 2-methylTHF at $20{ }^{\circ} \mathrm{C}$ : estimated error $\pm 5 \% .{ }^{d}$ The phosphorescence decay lifetimes of thin films prepared by spin-coating on quartz substrate from chlorobenzene solutions in poly(methyl methacrylate): estimated error $\pm 5 \%$. energy shoulder at $550 \mathrm{~nm}$ which indicates a higher contribution from the ${ }^{3} \mathrm{LC}$ states for this complex as a result of the additional functionality on the bridge increasing the structural rigidity (Fig. 5b).

The photoluminescence quantum yields (PLQYs) of 4, 5 and 6 in deoxygenated 2-methylTHF solutions are 5.6\%, 73\% and 63\%, respectively, compared with the reference complex $\operatorname{Ir}(\text { ppy })_{3}$ at 97\%. ${ }^{49}$ The very low QY for 4 is consistent with previously reported values for other $\mu$-dichloro-bridged dimers. ${ }^{15,16}$ The considerably higher quantum yields for 5 and $\mathbf{6}$ demonstrate that enhancement is induced by the oxamidato bridging unit, and the values are consistent with that reported previously for complex $2\left(\Phi_{\mathrm{PL}} 60 \%\right){ }^{32}$

The phosphorescence decay lifetimes of thin films of the complexes 4-6 prepared by spin-coating on quartz substrate from chlorobenzene solutions in poly(methyl methacrylate) (PMMA) are shown in Fig. 6. The data for complex 4 deviate from single exponential characteristics, and this is ascribed to the low solubility and aggregation behaviour of this complex in solution which leads to a strong lifetime dispersion corresponding to different aggregated states. Complexes 5 and 6 both have short phosphorescence lifetimes of 0.84 and $1.164 \mu \mathrm{s}$, respectively, originating from ${ }^{3}$ MLCT which indicates strong spin-orbital coupling with the singlet states.

\section{Computations}

Optimised geometries of complexes, 2, 4, 5 and $\mathbf{6}$, in meso $(\Delta \Lambda)$ and racemic $(\Delta \Delta / \Lambda \Lambda)$ forms were obtained by calculations using the hybrid DFT functional B3LYP. These geometries are in good agreement with their experimentally-determined molecular structures (Table S2, ESI $\dagger$ ). The meso form of $4(\Delta \Lambda)$ is not known experimentally due to steric constraints, as previously reported ${ }^{34}$ for the parent derivative $\operatorname{Ir}(\mathrm{ppy})_{2} \mathrm{Cl}_{2}$, with the total energy of $4(\Delta \Lambda)$ higher than $4(\Delta \Delta)$ by $9.0 \mathrm{kcal} \mathrm{mol}^{-1}$. The relative energy differences between meso $(\Delta \Lambda)$ and the more stable racemic $(\Delta \Delta)$ forms for 5 and $\mathbf{6}$ are only 2.6 and $2.1 \mathrm{kcal} \mathrm{mol}^{-1}$ respectively thus both forms would be observed as expected here.

Electronic structure calculations show that the frontier molecular orbitals for 4 resemble those reported ${ }^{17}$ for $\operatorname{Ir}(\mathrm{ppy})_{2} \mathrm{Cl}_{2}$ (Fig. 7). The HOMO has iridium and phenyl contributions whereas the LUMO contain pyridyl character (Table S3, ESI $\dagger$ ). Similar orbital make ups are found for meso $(\Delta \Lambda)$ and racemic $(\Delta \Delta)$ forms of 5 suggesting that the oxamidato bridges contribute little to the frontier orbitals (7-9\% bridging character in HOMO, 
(a)

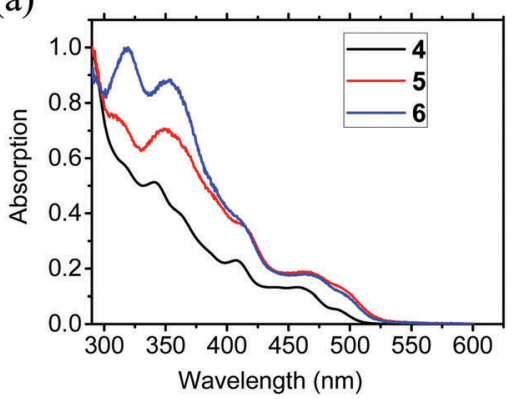

b)

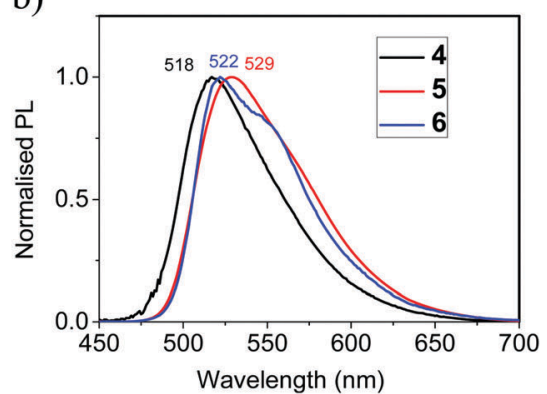

Fig. 5 (a) Normalised absorption spectra of complexes 4-6 in 2-methylTHF. (b) Photoluminescence spectra of complexes 4-6 in 2-methylTHF at $20^{\circ} \mathrm{C}$

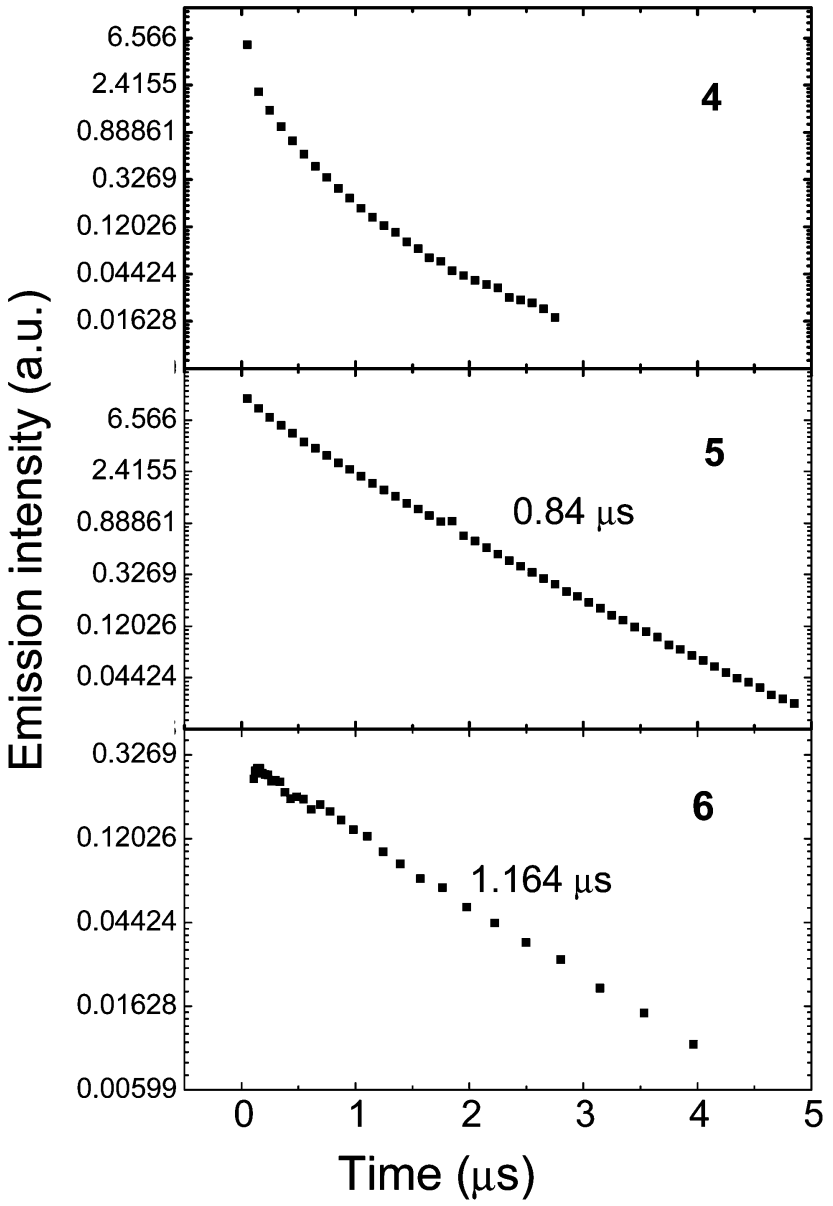

Fig. 6 Phosphorescence decays of the complexes doped at $5 \mathrm{wt} \%$ in inert PMMA matrix on a log-linear scale. Excitation wavelength $355 \mathrm{~nm}$.

Fig. 7 and Fig. S4 and Tables S4, S5, ESI $\dagger$ ). By contrast, the HOMO for complex $6(\Delta \Lambda)$ contains substantial oxamidato bridge character (35\%) along with HOMO-1 and HOMO-2 being similar in energies to the HOMO (Fig. 8 and Table S6, ESI $\dagger)$. Complex $6(\Delta \Delta)$ has the nature of HOMO, HOMO-1 and HOMO-2 in a different order while they all have similar energies (Fig. S5 and Table S7, ESI $\dagger$ ). The greater bridge involvement in the properties of $\mathbf{6}$ with respect to $\mathbf{5}$ is supported by cyclic voltammetry and photophysical observations here.
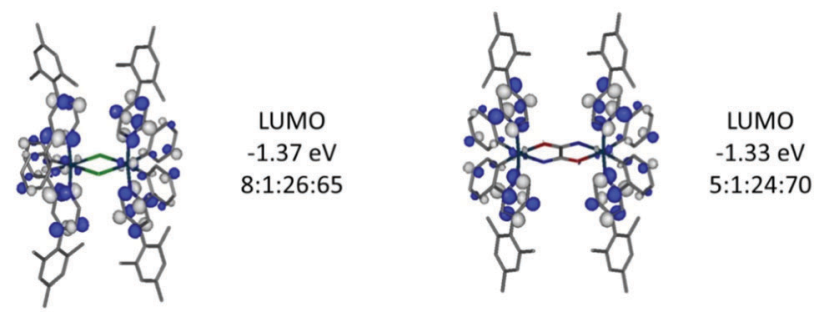

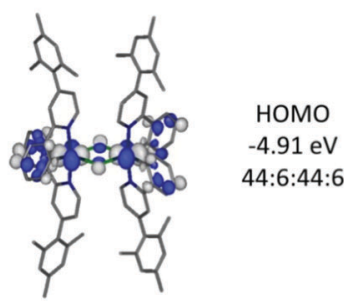

$4(\Delta \Delta)$

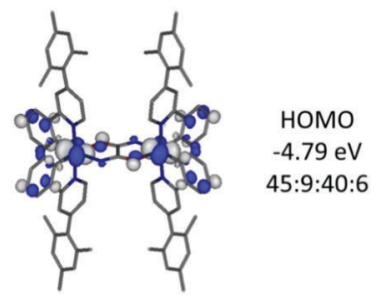

$5(\Delta \Lambda)$
Fig. 7 Frontier orbitals for $\mathbf{4}(\Delta \Delta)$ and $\mathbf{5}(\Delta \Lambda)$. Contour values are plotted at \pm 0.035 e bohr $^{-3}$. The Ir : bridge : phenyl : pyridyl ratios represent the atom/ group $\mathrm{MO}$ contributions in percentages.

The trend in the computed HOMO energies for $\mathbf{4 , 5}$ and $\mathbf{6}$ is in good agreement with measured oxidation potentials (Table 3). Complex 4 has a considerably lower HOMO energy than the HOMO energies in $\mathbf{5}$ and $\mathbf{6}$; thus $\mathbf{4}$ has a higher oxidation potential than 5 and 6. The calculated HOMO-LUMO energy gaps are similar at 3.54, 3.46 and $3.44 \mathrm{eV}$ for $\mathbf{4 , 5}$ and 6, respectively, and are in accord with the trend in the observed emission energies. This agreement is supported further by TD-DFT data where the observed lowest absorption energies are in excellent agreement with predicted $\mathrm{S}_{0} \rightarrow \mathrm{T}_{1}$ energies (Table $\mathrm{S} 8$, ESI $\dagger$ ).

\section{Electrophosphorescent OLED characterisation}

PhOLEDs were fabricated using complexes $\mathbf{5}$ or $\mathbf{6}$ as the dopant phosphor. Complex 4 was not studied because of its very low PLQY and very limited solubility. The device architecture comprised a simple single-emissive-layer which was a blend of poly(vinylcarbazole) (PVK) as the host material, OXD-7 (an electrontransporting material) and the Ir complex to give the architecture: ITO/PEDOT:PSS (45 nm)/PVK:OXD-7 (40\%):Ir complex (5\%) 

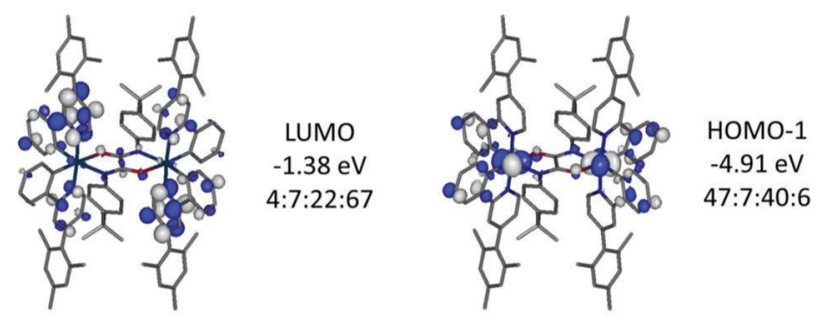

Both complexes show similar device characteristics, with slightly higher external quantum efficiency and power efficiency for 6 (Table 5). The reason for the differences between 5 and 6 is not clear, but the data suggest that attaching substituents to the bridge (as in 6) may be a viable design strategy to further enhance the EL efficiency. The electroluminescence (EL) emission maxima of the devices from both 5 and $6\left(\lambda_{\max }^{\mathrm{EL}} 533 \mathrm{~nm}\right)$ are slightly red shifted compared to the corresponding photoluminescence maxima of the complexes in solution (529 and $522 \mathrm{~nm}$, Table 1). The devices give green emission with a brightness $L_{\max }>25000 \mathrm{~cd} \mathrm{~m}^{-2}$ which is remarkably high for PhOLEDs fabricated using diiridium complexes. Compared to PhOLEDs of complex 1 under very similar conditions, ${ }^{34}$ the brightness of $\mathbf{5}$ and $\mathbf{6}$ is considerably higher, while the external quantum efficiency is lower. The moderate maximum external quantum efficiencies (EQE) for 5 and 6 ( $\left.\eta_{\text {ext }} c a .3-3.5 \%\right)$ indicate a significant dark current conduction through the device layers. It is well known that using PVK as a host and hole transporting layer can lead to increased device operating voltage and hence lower device power efficiency. ${ }^{51}$ Attempts were made to improve the EQE with an additional electron blocking layer consisting of poly[(9,9-dioctylfluorenyl2,7-diyl)-co-(4,4'-( $N$-(4-sec-butylphenyl)diphenylamine))] (TFB) ${ }^{52}$ which was spin-coated on the top of the PEDOT:PSS layer from toluene solution. This device structure required preparing and spinning the emissive layer using $N, N$-dimethylformamide (DMF) as solvent to avoid dissolving the TFB layer. Since the

(70 nm)/TPBi $(30 \mathrm{~nm}) / \mathrm{LiF} / \mathrm{Al}$. An electron transporting layer of TPBi was incorporated adjacent to the cathode to optimize charge balance and confine excitons in the emitter layer. ${ }^{50}$ The

current-voltage characteristics of the devices are shown in Fig. 9.

Fig. 8 Important orbitals for $6(\Delta \Lambda)$. Contour values are plotted at $\pm 0.035 \mathrm{e} \mathrm{bohr}^{-3}$. The Ir:bridge: phenyl: pyridyl ratios represent the atom/group $\mathrm{MO}$ contributions in percentages.
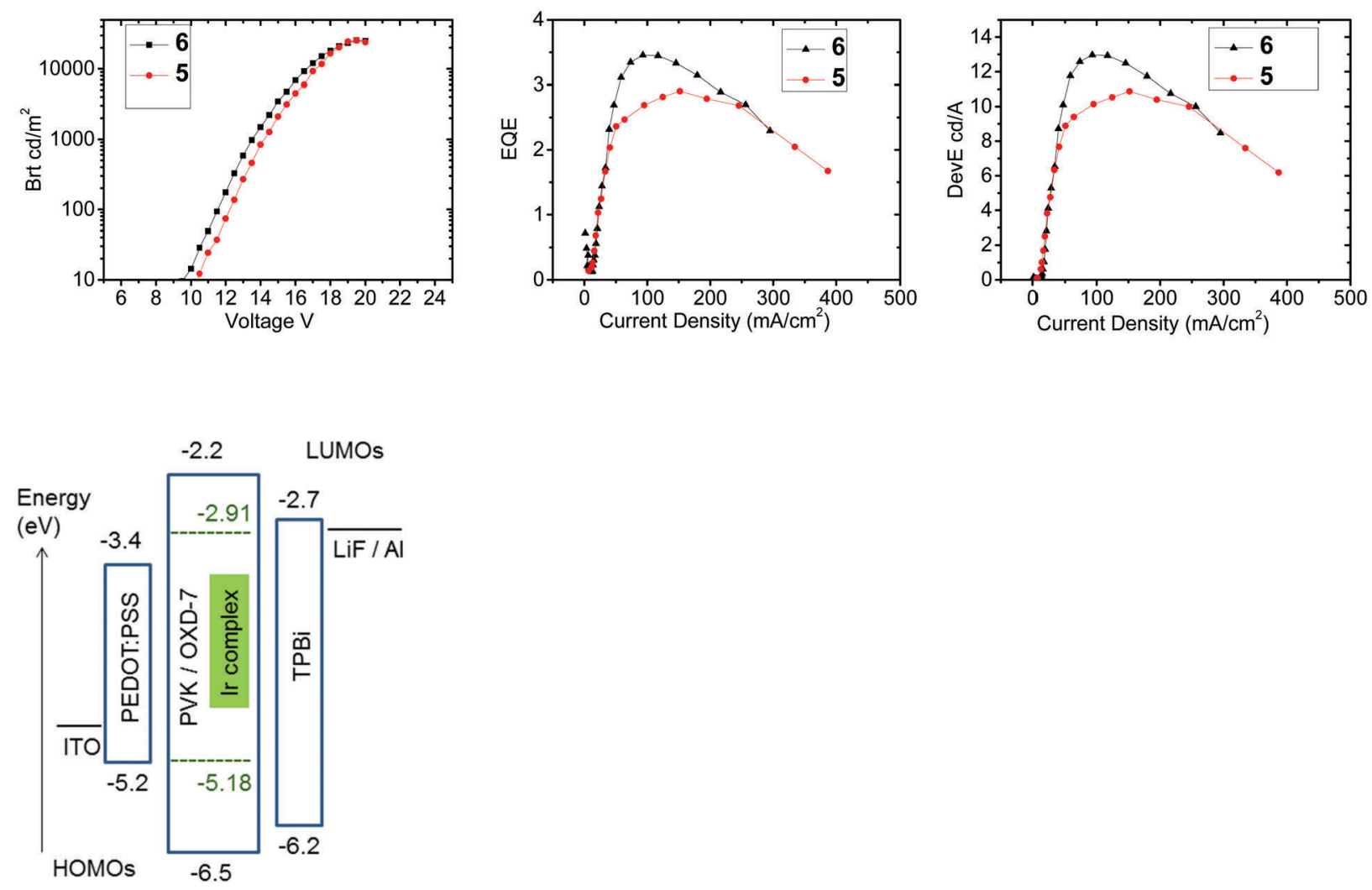

Fig. 9 Efficiencies and brightness data for complexes $\mathbf{5}$ and $\mathbf{6}$ in the device architecture stated in Table 5, and an energy level diagram for the devices. 
Table 5 Summary of electroluminescent device data. Device architecture: ITO/PEDOT:PSS (45 nm)/PVK:OXD-7 (40\%):Ir complex (5\%) (70 nm)/TPBi $(30 \mathrm{~nm}) / \mathrm{LiF} / \mathrm{Al}$

\begin{tabular}{|c|c|c|c|c|c|c|c|}
\hline Complex & $\lambda_{\max }^{\mathrm{EL} a} / \mathrm{nm}$ & $\begin{array}{l}\text { Maximum } \\
\text { brightness/cd m }\end{array}$ & EQE $\eta_{\text {ext }} / \%$ & $\begin{array}{l}\text { Current } \\
\text { efficiency/cd A }\end{array}$ & $\begin{array}{l}\text { Power efficiency/ } \\
\operatorname{lm~} \mathrm{W}^{-1}\end{array}$ & $\begin{array}{l}\text { Maximum radiant } \\
\text { power } / \mathrm{mW}\end{array}$ & $\begin{array}{l}\mathrm{CIE}_{x, y} \\
\text { coordinates }\end{array}$ \\
\hline 5 & 533 & 25400 & 2.95 & 13 & 1.9 & 1.22 & $0.34,0.63$ \\
\hline
\end{tabular}

high molecular weight PVK used as the host in the initial devices is insoluble in DMF, low molecular weight PVK $\left(M_{\mathrm{w}} 90000\right)$ which dissolves in DMF was used instead. The device efficiency and brightness with low molecular weight PVK is extremely low $(<0.1 \%)$. However, by including the TFB layer the $\mathrm{EQE}_{\max }$ of the low molecular weight PVK device improved from $3.5 \%$ (Table 5) to $c a$. $4 \%$ (Fig S13, ESI $\dagger$ ). We have not explored alternative more complex device structures, as our aim in this work is to use a simpler single-active-layer solutionprocessable structure which is applicable to low-cost, large-area devices and panels for lighting applications. It is notable that the data for $\mathbf{5}$ and $\mathbf{6}$ strongly compete with the brightest reported PhOLEDs using bimetallic complexes as the emitter. They are more than twice as bright, although with lower EQE, than comparable PhOLEDs using complex 1 (maximum brightness $11000 \mathrm{~cd} \mathrm{~m}^{-2}$; $\mathrm{EQE}_{\max } 7 \%$; green emission). ${ }^{34}$ Electroluminescence data for other diiridium PhOLEDs are as follows: (bridge; brightness; EQE; colour). (i) $\mu$-Dichloro; $13000 \mathrm{~cd} \mathrm{~m}^{-2}$; $0.8 \%$; green. ${ }^{16}$ (ii) $\mu$-Dichloro; $3700 \mathrm{~cd} \mathrm{~m}^{-2}$; $3.2 \%$; green. ${ }^{17}$ (iii) $\mu$-Dichloro; $6000 \mathrm{~cd} \mathrm{~m}^{-2}$; 2.6\%; green. ${ }^{36 a}$ (iv) Diarylpyrimidinyl; $18410 \mathrm{~cd} \mathrm{~m}^{-2} ; 14.4 \%$; red. ${ }^{33}$ (v) Fluorenyl; $1040 \mathrm{~cd} \mathrm{~m}^{-2}$; nearwhite. ${ }^{36 b}$ For a cationic diiridium complex with a carbazolyl bridge; $1022 \mathrm{~cd} \mathrm{~m}^{-2}$; yellow-orange. ${ }^{37}$

The PhOLED data for $\mathbf{5}$ and $\mathbf{6}$ are, therefore, significantly different from data on other diiridium complexes studied in our laboratory, ${ }^{16,17,34}$ and elsewhere, ${ }^{33,36}$ demonstrating that properties can be tuned by varying the bridge structure. The high molecular weight of diiridium complexes generally precludes their fabrication into thin films by thermal evaporation, therefore, they are unlikely to achieve the very high EQEs which characterise PhOLEDs of mono-iridium complexes which are deposited by vacuum deposition. ${ }^{53}$ However, high brightness, as observed for $\mathbf{5}$ and $\mathbf{6}$, is widely recognised as an important figure-of-merit for PhOLED characterisation. ${ }^{52}$ Moreover, the solution-processability of the host-dopant systems is especially attractive for the construction of large-area electronics for relatively low-cost practical applications via spin-coating, roll-to-roll processing or ink-jet printing. ${ }^{54}$

\section{Conclusions}

Compared to the vast number of mononuclear iridium complexes used in PhOLEDs, the study of dinuclear complexes in this context is an emerging and very promising topic for further research. In this work we have described the synthesis, X-ray crystal structures and optoelectronic properties of the new cyclometalated diiridium complexes $\mathbf{5}$ and $\mathbf{6}$ bridged by oxamidato ligands. In particular, a novel structural feature is that complex 6 provides the first reported example with any substituent (other than hydrogens) on the oxamidato bridge. The complexes are highly emissive ( $\Phi_{\mathrm{PL}} 73 \%$ and $63 \%$ in solution) with short excited state lifetimes of $\tau_{\mathrm{P}} 0.84$ and $1.16 \mu \mathrm{s}$, respectively. PhOLEDs using complexes 5 and $\mathbf{6}$ as the emissive dopants in a simple architecture using a solution-processed active layer give bright green electroluminescence with remarkably high luminance $\left(L_{\max }>25000 \mathrm{~cd} \mathrm{~m}^{-2}\right)$ for diiridium complexes. These studies expand the range of diiridium complexes that are suitable as dopants for PhOLED applications and should stimulate further studies on chemically tailoring the structures of diiridium complexes to yield highly emissive and colour-tunable systems.

\section{Experimental}

\section{General}

All commercial chemicals were used without further purification unless otherwise stated. Solvents were dried through an HPLC column on an Innovative Technology Inc. solvent purification system. Column chromatography was carried out using 40-60 $\mu \mathrm{m}$ mesh silica. ${ }^{1} \mathrm{H},{ }^{13} \mathrm{C}\left\{{ }^{1} \mathrm{H}\right\}, 2 \mathrm{D}{ }^{1} \mathrm{H}-{ }^{1} \mathrm{H}$ COSY and ${ }^{1} \mathrm{H}^{13}{ }^{13} \mathrm{C}$ correlation (HSQC and HMBC) NMR spectra were recorded on a solutionstate Varian VNMRS-700 spectrometer. The proton chemical shifts are referenced to $\mathrm{CHCl}_{3}(7.25 \mathrm{ppm})$ or $\mathrm{CHDCl}_{2}(5.32 \mathrm{ppm})$ present in $\mathrm{CDCl}_{3}$ and $\mathrm{CD}_{2} \mathrm{Cl}_{2}$ solutions, respectively. The ${ }^{13} \mathrm{C}$ chemical shifts are referenced to the deuterated solvent $\mathrm{CDCl}_{3}$ or $\mathrm{CD}_{2} \mathrm{Cl}_{2}$ at 77.00 and $53.38 \mathrm{ppm}$, respectively. Mass spectra were measured on a Waters Xevo OTof MS with an ASAP probe, a Thermoquest Trace or a Thermo-Finnigan DSQ. Elemental analyses were performed on a CE-400 Elemental Analyzer. Thermal analysis was performed in a helium atmosphere using a Perkin-Elmer Pyris 1 instrument.

\section{Synthesis}

Tetrakis[2-phenyl-4-(2,4,6-trimethylphenyl)pyridine- $\left.C^{2}, N^{\prime}\right]-$ bis( $\mu$-chloro)diiridium(III) (4). A mixture of ligand 3 (0.95 g, $3.47 \mathrm{mmol}), \mathrm{IrCl}_{3} \cdot 3 \mathrm{H}_{2} \mathrm{O}(0.55 \mathrm{mg}, 1.56 \mathrm{mmol})$, 2-ethoxyethanol $(20 \mathrm{ml})$ and water $(10 \mathrm{ml})$ was heated with stirring at $120{ }^{\circ} \mathrm{C}$ for $12 \mathrm{~h}$. An orange precipitation formed after $1 \mathrm{~h}$. The reaction mixture was cooled to room temperature and filtered; the precipitate was washed with water $(2 \times 50 \mathrm{ml})$, dissolved in DCM $(150 \mathrm{ml})$, dried over magnesium sulphate and the solvent evaporated. Purification by column chromatography over silica gel, eluting with DCM yielded 4 as an orange solid $(0.80 \mathrm{~g}, 66 \%)$. 
MS(MALDI-TOF) $m / z 1544.4\left(\left[\mathrm{M}^{+},{ }^{191} \mathrm{Ir},{ }^{193} \mathrm{Ir},{ }^{35} \mathrm{Cl},{ }^{37} \mathrm{Cl}\right.\right.$ or ${ }^{191} \mathrm{Ir}$, ${ }^{191} \mathrm{Ir},{ }^{37} \mathrm{Cl},{ }^{37} \mathrm{Cl}$ or $\left.\left.{ }^{193} \mathrm{Ir},{ }^{193} \mathrm{Ir},{ }^{35} \mathrm{Cl},{ }^{35} \mathrm{Cl}\right], 100 \%\right)$.

Anal. calcd for $\mathrm{C}_{80} \mathrm{H}_{72} \mathrm{Cl}_{2} \mathrm{Ir}_{2} \mathrm{~N}_{4}$ : C, 62.20; H, 4.70; N, 3.63. Found: C, 61.59; H, 4.56; N, 3.60\%.

${ }^{1} \mathrm{H}$ NMR $\left(700 \mathrm{MHz}, \mathrm{CD}_{2} \mathrm{Cl}_{2}\right) \delta 9.67\left(\mathrm{~d},{ }^{3} J_{\mathrm{HH}}=5.5 \mathrm{~Hz}, 4 \mathrm{H}\right.$, $\mathrm{C} 6 \mathrm{H}), 7.74(\mathrm{~s}, 4 \mathrm{H}, \mathrm{C} 3 \mathrm{H}), 7.51\left(\mathrm{~d},{ }^{3} \mathrm{JHH}_{\mathrm{HH}}=8.0 \mathrm{~Hz}, 4 \mathrm{H}, \mathrm{C} 8 \mathrm{H}\right), 7.04$ (s, 4H, C15H), $7.01(\mathrm{~s}, 4 \mathrm{H}, \mathrm{C} 17 \mathrm{H}), 6.83(\mathrm{~m}, 8 \mathrm{H}, \mathrm{C} 5 \mathrm{H}$ and $\mathrm{C} 9 \mathrm{H})$, $6.68\left(\mathrm{dd},{ }^{3} J_{\mathrm{HH}} \sim 7.5 \mathrm{~Hz}, 4 \mathrm{H}, \mathrm{C} 10 \mathrm{H}\right), 5.92\left(\mathrm{~d},{ }^{3} \mathrm{~J}_{\mathrm{HH}}=8.0 \mathrm{~Hz}\right.$, $4 \mathrm{H}, \mathrm{C} 11 \mathrm{H}), 2.39$ (s, 12H, C16Me), 2.13 (s, 12H, C18Me), 2.12 (s, 12H, C14Me).

${ }^{13} \mathrm{C}\left\{{ }^{1} \mathrm{H}\right\}$ NMR (176 MHz, $\left.\mathrm{CD}_{2} \mathrm{Cl}_{2}\right) \delta 168.49$ (C2), 151.58 (C6), 150.80 (C4), 144.50 (C12), 144.11 (C7), 137.90 (C16), 135.33 (C13), 135.49 (C14), 134.62 (C18), 130.03 (C11), 129.32 (C10), 128.52 (C15), 128.23 (C17), 123.71 (C8), 123.44 (C5), 121.42 (C9), 120.41 (C3), 20.79 (C16Me), 20.46 (C18Me), 20.21 (C14Me). Complex 4 was very recently reported elsewhere and analysed by ${ }^{1} \mathrm{H}$ NMR spectroscopy. ${ }^{40,41}$

Tetrakis[2-phenyl-4-(2,4,6-trimethylphenyl)pyridine- $\left.C^{2}, N^{\prime}\right]-$ bis( $\mu$-oxamidato- $\left.N, N^{\prime}, O, O^{\prime}\right)$ diiridium(III) (5). A mixture of sodium methoxide ( $40.7 \mathrm{mg}, 2.6 \mathrm{eq}$.) in methanol $(1.5 \mathrm{ml})$ and oxamide $\left(33.2 \mathrm{mg}\right.$, 1.3 eq.) in methanol $(10 \mathrm{ml})$ was stirred at $20{ }^{\circ} \mathrm{C}$ for $30 \mathrm{~min}$. Complex $4(0.45 \mathrm{~g}, 0.29 \mathrm{mmol})$ in THF $(30 \mathrm{ml})$ was added and the white solution became an orange suspension. The mixture was stirred at $20{ }^{\circ} \mathrm{C}$ for $24 \mathrm{~h}$. Solvent was removed and the residue was dissolved in DCM $(50 \mathrm{ml})$. Water $(25 \mathrm{ml})$ was added and DCM layer was separated and dried with magnesium sulphate then filtered. Methanol $(25 \mathrm{ml})$ was added to the DCM layer and the combined solvent was partially evaporated using a rotavapor. The solid which formed was removed by filtration and washed with methanol. Column chromatography on silica gel, eluting with DCM (saturated with $\mathrm{K}_{2} \mathrm{CO}_{3}$ ) yielded 5 as a yellow-orange coloured solid (0.272 mg, 60\%). MS(MALDI-TOF) $\mathrm{m} / z 1560.51$ ([M + H, ${ }^{191} \mathrm{Ir}$, $\left.{ }^{193} \mathrm{Ir}\right], 100 \%$ ). Anal. calcd for $\mathrm{C}_{82} \mathrm{H}_{74} \mathrm{Ir}_{2} \mathrm{~N}_{6} \mathrm{O}_{2} \cdot 3 \mathrm{CH}_{2} \mathrm{Cl}_{2}: \mathrm{C}, 56.26 ; \mathrm{H}$, 4.44; N, 4.63. Found: C, 56.42; H, 4.33; N, 4.55\%. Recrystallisation from a mixture of hexane and chlorobenzene gave crystals suitable for X-ray analysis.

${ }^{1} \mathrm{H}$ NMR $\left(700 \mathrm{MHz}, \mathrm{CDCl}_{3}\right) \delta$ major isomer $8.94\left(\mathrm{~d},{ }^{3} \mathrm{~J}_{\mathrm{HH}}=\right.$ $5.7 \mathrm{~Hz}, 2 \mathrm{H}, \mathrm{C} 6 \mathrm{H}), 8.82\left(\mathrm{~d},{ }^{3} \mathrm{~J}_{\mathrm{HH}}=5.6,2 \mathrm{H}, \mathrm{C} 6^{\prime} \mathrm{H}\right), 7.64(\mathrm{~s}, 2 \mathrm{H}, \mathrm{C} 3 \mathrm{H})$, $7.61\left(\mathrm{~s}, 2 \mathrm{H}, \mathrm{C}^{\prime} \mathrm{H}\right), 7.49\left(\mathrm{~d},{ }^{3} J_{\mathrm{HH}} \sim 7.6,2 \mathrm{H}, \mathrm{C} 8 \mathrm{H}\right), 7.45\left(\mathrm{~d},{ }^{3} J_{\mathrm{HH}}=\right.$ $\left.7.6,2 \mathrm{H}, \mathrm{C} 8^{\prime} \mathrm{H}\right), 7.03\left(\mathrm{dd},{ }^{3} \mathrm{~J}_{\mathrm{HH}}=5.7, J_{\mathrm{HH}}=1.9 \mathrm{~Hz}, 2 \mathrm{H}, \mathrm{C} 5 \mathrm{H}\right), 7.02(\mathrm{~s}$, $\left.2 \mathrm{H}, \mathrm{C} 15^{\prime} \mathrm{H}\right), 7.00(\mathrm{~s}, 2 \mathrm{H}, \mathrm{C} 15 \mathrm{H}), 6.97(\mathrm{~s}, 2 \mathrm{H}, \mathrm{C} 17 \mathrm{H}), 6.95(\mathrm{~s}, 2 \mathrm{H}$, $\left.\mathrm{C}^{\prime} 7^{\prime} \mathrm{H}\right), 6.85\left(\mathrm{dd},{ }^{3} J_{\mathrm{HH}}=5.7, J_{\mathrm{HH}}=1.9 \mathrm{~Hz}, 2 \mathrm{H}, \mathrm{C}^{\prime} \mathrm{H}\right), 6.81-6.75$ $\left(\mathrm{m}, 4 \mathrm{H}, \mathrm{C} 9 \mathrm{H}, \mathrm{C} 9^{\prime} \mathrm{H}\right), 6.73-6.67\left(\mathrm{~m}, 4 \mathrm{H}, \mathrm{C} 10 \mathrm{H}, \mathrm{C} 10^{\prime} \mathrm{H}\right), 6.35$ (d, $\left.{ }_{3}^{3}{ }_{\mathrm{HH}} \sim 7.7,2 \mathrm{H}, \mathrm{C} 11 \mathrm{H}\right), 6.30(\mathrm{~s}, 2 \mathrm{H}, \mathrm{NH}), 6.25\left(\mathrm{~d},{ }^{3} J_{\mathrm{HH}} \sim 7.7\right.$, $\left.2 \mathrm{H}, \mathrm{C} 11^{\prime} \mathrm{H}\right), 2.39(\mathrm{~s}, 6 \mathrm{H}, \mathrm{C} 16 \mathrm{Me}), 2.37$ (s, 6H, C16'Me), 2.16 (s, 6H, C14Me), 2.14 (s, 6H, C14'Me), 2.02 (s, 6H, C18'Me), 1.99 $(\mathrm{s}, 6 \mathrm{H}, \mathrm{C} 18 \mathrm{Me})$. Minor isomer $8.68\left(\mathrm{~d},{ }^{3} J_{\mathrm{HH}}=5.6,2 \mathrm{H}, \mathrm{C} 6 \mathrm{H}\right), 8.63$ $\left(\mathrm{d},{ }^{3} J_{\mathrm{HH}}=5.7,2 \mathrm{H}, \mathrm{C} 6^{\prime} \mathrm{H}\right), 7.68(\mathrm{~s}, 2 \mathrm{H}, \mathrm{C} 3 \mathrm{H}), 7.65\left(\mathrm{~s}, 2 \mathrm{H}, \mathrm{C} 3^{\prime} \mathrm{H}\right), 7.51$ $\left(\mathrm{d},{ }^{3} J_{\mathrm{HH}}=7.6,2 \mathrm{H}, \mathrm{C} 8 \mathrm{H}\right), 7.48\left(\mathrm{~d},{ }^{3} J_{\mathrm{HH}} \sim 7.6,2 \mathrm{H}, \mathrm{C}{ }^{\prime} \mathrm{H}\right), 7.03(\mathrm{~s}, 2 \mathrm{H}$, $\mathrm{C} 17 \mathrm{H}), 7.02$ (s, 4H, C15H, C15'H), $6.98\left(\mathrm{~s}, 2 \mathrm{H}, \mathrm{C}^{\prime} 7^{\prime} \mathrm{H}\right), 6.84$ $\left(\mathrm{dd},{ }^{3} J_{\mathrm{HH}}=5.7, J_{\mathrm{HH}}=1.9,2 \mathrm{H}, \mathrm{C} 5 \mathrm{H}\right), 6.81-6.75(\mathrm{~m}, 4 \mathrm{H}, \mathrm{C} 9 \mathrm{H}$, $\left.\mathrm{C}^{\prime} \mathrm{H}\right), 6.76\left(\mathrm{dd},{ }^{3} J_{\mathrm{HH}} \sim 5.7, J_{\mathrm{HH}}=1.9,2 \mathrm{H}, \mathrm{C} 5^{\prime} \mathrm{H}\right), 6.73-6.67(\mathrm{~m}$, $\left.2 \mathrm{H}, \mathrm{C} 10 \mathrm{H}, \mathrm{C} 10^{\prime} \mathrm{H}\right), 6.35\left(\mathrm{~d},{ }^{3} \mathrm{JHH}_{\mathrm{HH}} \sim 7.7,2 \mathrm{H}, \mathrm{C} 11 \mathrm{H}\right), 6.29(\mathrm{~s}, 2 \mathrm{H}, \mathrm{NH})$, $6.25\left(\mathrm{~d},{ }^{3} J_{\mathrm{HH}} \sim 7.7,2 \mathrm{H}, \mathrm{C} 11^{\prime} \mathrm{H}\right), 2.38$ (s, 12H, C16Me, C16 $\left.{ }^{\prime} \mathrm{Me}\right), 2.16$ (s, 6H, C14Me, C14'Me), 2.10 (s, 6H, C18Me), 2.07 (s, 6H, C18'Me).
${ }^{13} \mathrm{C}\left\{{ }^{1} \mathrm{H}\right\}$ NMR (176 MHz, $\left.\mathrm{CDCl}_{3}\right) \delta$ major isomer 174.46 (CO). 169.23 (C2), 168.98 (C2'), 154.78 (C12), 150.58 (C4), 149.88 (C4'), 149.02 (C6), 147.76 (C6'), 144.78 (C12'), 144.32 (C7), 144.30 (C7'), 137.93 (C16), 137.89 (C16'), 135.82 (C13), 135.79 (C13'), 135.45 (C14), 135.33 (C14'), 135.13 (C18), 134.98 (C18'), 132.52 (C11), 132.11 (C11'), 129.54 (C10), 129.34 (C10'), 128.58 (C15), 128.56 (C15'), 128.48 (C17), 128.35 (C17'), 124.26 (C8), 123.87 (C8'), 122.41 (C5), 122.38 (C5'), 120.69 (C9), 120.36 (C9'), 119.86 (C3), 119.42 (C3'), 21.08 (C16Me), 21.05 (C16'Me), 20.85 (C18Me), 20.82 (C18'Me), 20.59 (C14Me), 20.56 (C14'Me). Minor isomer 174.35 (CO), 169.20 (C2), 168.91 (C2'), 154.71 (C12), 150.48 (C4), $149.72\left(\mathrm{C}^{\prime}\right), 149.23$ (C6), 147.65 (C6'), 144.78 (C12'), 144.35 (C7), 144.25 (C7'), 137.83 (C16, C16'), 135.79 (C13, C13'), 135.36 (C14), 135.33 (C14'), 135.20 (C18), 135.01 (C18'), 132.66 (C11), 132.24 (C11'), 129.50 (C10), 129.39 (C10'), 128.53 (C15), 128.52 (C15'), 128.41 (C17, C17'), 124.29 (C8), 123.85 (C8'), 122.51 (C5), 122.50 (C5'), 120.72 (C9), 120.38 (C9'), 119.76 (C3), 119.45 (C3'), 21.08 (C16Me), 21.07 (C16'Me), 20.76 (C18Me), 20.61 (C18'Me), 20.53 (C14Me, C14'Me).

Tetrakis[2-phenyl-4-(2,4,6-trimethylphenyl)pyridine- $\left.C^{2}, N^{\prime}\right]-$ bis( $\left(\mu\right.$-oxamidato-anti- $N, N^{\prime}$-bis(4-tert-butylphenyl),O, $\left.O^{\prime}\right)$ diiridium(III) (6). A mixture of sodium methoxide $(29.5 \mathrm{mg}, 2.8$ eq.) in methanol $(1 \mathrm{ml})$, and $N, N^{\prime}$-bis(4-tert-butylphenyl)oxamide ${ }^{55}$ (95.8 mg, 1.4 eq.) in methanol $(7 \mathrm{ml})$ was stirred at $20{ }^{\circ} \mathrm{C}$ for $30 \mathrm{~min}$. Complex $4(0.30 \mathrm{~g}, 0.19 \mathrm{mmol})$ in THF $(20 \mathrm{ml})$ was added. The procedure for complex 5 was followed. Column chromatography of the crude product on silica gel, eluting with DCM: hexane $(1: 1 \mathrm{v} / \mathrm{v})$ (the DCM was saturated with $\left.\mathrm{K}_{2} \mathrm{CO}_{3}\right)$ yielded a light orange solid $6(0.225 \mathrm{mg}, 64 \%)$ which was recrystallised from a mixture of pentane and chlorobenzene.

MS(MALDI-TOF) $\mathrm{m} / \mathrm{z} 1824.70$ ([M + H, $\left.{ }^{191} \mathrm{Ir},{ }^{193} \mathrm{Ir}\right], 100 \%$ ). Anal. calcd For $\mathrm{C}_{102} \mathrm{H}_{98} \mathrm{Ir}_{2} \mathrm{~N}_{6} \mathrm{O}_{2}$ : C, 66.75; H, 5.32; N, 4.55. Found: C, 67.15; H, 5.41; N, 4.61\%.

${ }^{1} \mathrm{H}$ NMR $\left(700 \mathrm{MHz}, \mathrm{CD}_{2} \mathrm{Cl}_{2}\right) \delta$ major isomer $9.03\left(\mathrm{~d},{ }^{3} J_{\mathrm{HH}}=\right.$ $5.7,2 \mathrm{H}, \mathrm{C} 6 \mathrm{H}), 8.77\left(\mathrm{~d},{ }^{3} \mathrm{JHH}_{\mathrm{HH}} \sim 5.7,2 \mathrm{H}, \mathrm{C}^{\prime} \mathrm{H}\right), 7.76(\mathrm{~s}, 2 \mathrm{H}, \mathrm{C} 3 \mathrm{H})$, $7.59\left(\mathrm{~d},{ }^{3} \mathrm{JHH}_{\mathrm{HH}} \sim 7.6,2 \mathrm{H}, \mathrm{C} 8 \mathrm{H}\right), 7.45\left(\mathrm{~s}, 2 \mathrm{H}, \mathrm{C} 3^{\prime} \mathrm{H}\right), 7.35(\mathrm{~s}, 4 \mathrm{H}$, $\left.\mathrm{C} 17 \mathrm{H}, \mathrm{C}^{\prime} 7^{\prime} \mathrm{H}\right), 7.10\left(\mathrm{~s}, 4 \mathrm{H}, \mathrm{C} 15 \mathrm{H}, \mathrm{C} 15^{\prime} \mathrm{H}\right), 7.03(\mathrm{dd}, 2 \mathrm{H}, \mathrm{C} 5 \mathrm{H})$, $7.02\left(\mathrm{~d}, 2 \mathrm{H}, \mathrm{C} 8^{\prime} \mathrm{H}\right), 6.98\left(\mathrm{dd}, 2 \mathrm{H}, \mathrm{C}^{\prime} \mathrm{H}\right), 6.84\left(\mathrm{dd},{ }^{3} J_{\mathrm{HH}} \sim 7.5\right.$, $2 \mathrm{H}, \mathrm{C} 9 \mathrm{H}), 6.74(\mathrm{~m}, 2 \mathrm{H}, \mathrm{C} 10 \mathrm{H}), 6.72\left(\mathrm{~d},{ }^{3} \mathrm{~J}_{\mathrm{HH}}=8.6,4 \mathrm{H}, \mathrm{C} 21 / 23 \mathrm{H}\right)$, $6.58\left(\mathrm{dd}, 2 \mathrm{H}, \mathrm{C} 9^{\prime} \mathrm{H}\right), 6.55\left(\mathrm{~m}, 2 \mathrm{H}, \mathrm{C} 10^{\prime} \mathrm{H}\right), 6.49\left(\mathrm{~d},{ }^{3} J_{\mathrm{HH}}=7.8,2 \mathrm{H}\right.$, $\mathrm{C} 11 \mathrm{H}), 6.25\left(\mathrm{~d},{ }^{3} J_{\mathrm{HH}}=8.6,4 \mathrm{H}, \mathrm{C} 20 / 24 \mathrm{H}\right), 6.15\left(\mathrm{~d},{ }^{3} J_{\mathrm{HH}}=7.8,2 \mathrm{H}\right.$, $\left.\mathrm{C}_{11}{ }^{\prime} \mathrm{H}\right), 2.38$ (s, 12H, C16Me, C16 $\left.{ }^{\prime} \mathrm{Me}\right), 2.26$ (s, 6H, C18 ${ }^{\prime} \mathrm{Me}$ ), 2.21 (s, 6H, C14Me), 2.19 (s, 6H, C18Me), 2.18 (s, 6H, C14'Me), $1.10\left(\mathrm{~s}, \mathrm{CMe}_{3}\right)$. Minor isomer $9.25\left(\mathrm{~d},{ }^{3} \mathrm{JHH}_{\mathrm{HH}}=5.6,2 \mathrm{H}, \mathrm{C} 6 \mathrm{H}\right), 8.83$ $\left(\mathrm{d},{ }^{3} J_{\mathrm{HH}} \sim 5.6,2 \mathrm{H}, \mathrm{C} 6{ }^{\prime} \mathrm{H}\right), 7.76(\mathrm{~s}, 2 \mathrm{H}, \mathrm{C} 3 \mathrm{H}), 7.60\left(\mathrm{~d},{ }^{3} J_{\mathrm{HH}} \sim 7.6\right.$, $2 \mathrm{H}, \mathrm{C} 8 \mathrm{H}), 7.40\left(\mathrm{~s}, 2 \mathrm{H}, \mathrm{C} 3^{\prime} \mathrm{H}\right), 7.35\left(\mathrm{~s}, 4 \mathrm{H}, \mathrm{C} 17 \mathrm{H}, \mathrm{C} 17^{\prime} \mathrm{H}\right), 7.10$ $\left(\mathrm{s}, 4 \mathrm{H}, \mathrm{C} 15 \mathrm{H}, \mathrm{C} 15^{\prime} \mathrm{H}\right), 7.10\left(\mathrm{dd},{ }^{3} J_{\mathrm{HH}}=7.2, J_{\mathrm{HH}}=2.0,2 \mathrm{H}, \mathrm{C} 5 \mathrm{H}\right)$, $7.04\left(\mathrm{~d}, 2 \mathrm{H}, \mathrm{C} 8^{\prime} \mathrm{H}\right), 7.04\left(\mathrm{dd}, 2 \mathrm{H}, \mathrm{C5}^{\prime} \mathrm{H}\right), 6.84(\mathrm{dd}, 2 \mathrm{H}, \mathrm{C} 9 \mathrm{H}), 6.74$ $(\mathrm{m}, 2 \mathrm{H}, \mathrm{C} 10 \mathrm{H}), 6.68\left(\mathrm{~d},{ }^{3} J_{\mathrm{HH}}=8.6,4 \mathrm{H}, \mathrm{C} 21 / 23 \mathrm{H}\right), 6.58(\mathrm{dd}$, $\left.2 \mathrm{H}, \mathrm{C} 9^{\prime} \mathrm{H}\right), 6.55\left(\mathrm{~m}, 2 \mathrm{H}, \mathrm{C} 10^{\prime} \mathrm{H}\right), 6.41\left(\mathrm{~d},{ }^{3} \mathrm{~J}_{\mathrm{HH}}=7.7,2 \mathrm{H}, \mathrm{C} 11 \mathrm{H}\right)$, $6.22\left(\mathrm{~d},{ }^{3} J_{\mathrm{HH}}=8.6,4 \mathrm{H}, \mathrm{C} 20 / 24 \mathrm{H}\right), 6.27\left(\mathrm{~d},{ }^{3} \mathrm{~J}_{\mathrm{HH}}=7.8,2 \mathrm{H}, \mathrm{C} 11^{\prime} \mathrm{H}\right)$, 2.41 (s, 6H, C16Me), 2.39 (s, 6H, C16'Me), 2.24 (s, 6H, C14Me), 2.15 (s, 6H, C14 ${ }^{\prime} \mathrm{Me}$ ), 2.02 (s, 6H, C18 ${ }^{\prime} \mathrm{Me}$ ), 1.97 (s, 6H, C18Me), $1.09\left(\mathrm{~s}, \mathrm{CMe}_{3}\right)$.

${ }^{13} \mathrm{C}\left\{{ }^{1} \mathrm{H}\right\}$ NMR (176 MHz, $\left.\mathrm{CD}_{2} \mathrm{Cl}_{2}\right) \delta$ major isomer 171.66 (CO), 169.43 (C2), 168.39 (C2'), 152.88 (C12), 150.77 (C4), 
150.52 (C4'), 149.35 (C6), $148.45\left(\mathrm{C} 12^{\prime}\right), 147.50\left(\mathrm{C6}^{\prime}\right), 145.87$ (C22), 145.05 (C7), 143.47 (C7'), 141.79 (C19), 137.90 (C16), 137.88 (C16'), 135.92 (C13), 135.73 (C13'), 135.28 (C14), 135.27 (C14'), 134.86 (C18, C18'), 133.24 (C11), 131.75 (C11'), 129.13 (C10), 128.86 (C10'), 128.40 (C15, C15', C17), 128.36 (C17'), 124.31 (C8), 124.02 (C21/23), 123.53 (C20/24), 123.52 (C8'), 122.88 (C5), 122.20 (C5'), 120.91 (C9), 120.47 (C3), 119.73

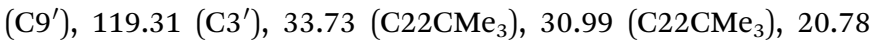
(C16Me, C16'Me), 20.58 (C18Me), 20.57 (C18'Me), 20.39 (C14Me), 20.31 (C14'Me). Minor isomer 171.62 (CO), 169.45 (C2), 168.21 (C2'), 152.96 (C12), 150.77 (C4), 150.27 (C4'), 149.23 (C6), 148.64 (C12'), 147.63 (C6'), 145.67 (C22), 145.00 (C7), 143.43 (C7'), 142.10 (C19), 137.92 (C16), 137.82 (C16'), 135.78 (C13), $135.73\left(\mathrm{C} 13^{\prime}\right), 135.28$ (C14, C14'), 135.01 (C18, C18'), 133.09 (C11), 132.05 (C11'), 129.23 (C10), 128.88 (C10'), 128.40 (C15, C15'), 128.26 (C17), 128.19 (C17'), 124.26 (C8), 123.98 (C21/23), 123.64 (C20/24),123.40 (C8'), 122.83 (C5), $122.30\left(\mathrm{C5}^{\prime}\right)$, 120.78 (C9), 120.19 (C3), 119.71 (C9'), 119.19 (C3'), 33.71 $\left(\mathrm{C} 22 \mathrm{CMe}_{3}\right), 30.97\left(\mathrm{C} 22 \mathrm{CMe}_{3}\right), 20.81$ (C16Me), 20.78 (C16'Me), 20.55 (C18Me), 20.49 (C18'Me), 20.37 (C14Me), 20.27 (C14'Me).

\section{X-ray crystallography}

The data for 5 was collected on a Rigaku Crystal Logic 4-circle $\kappa$-diffractometer with a Saturn 724+ CCD area detector at Station I19 of the Diamond Light Source synchrotron (undulator radiation, double-crystal Si monochromator, $\lambda=0.6889 \AA$, $\omega$-scans, $1.0^{\circ}$ per frame), and for 6 on a Bruker 3-circle CCD diffractometer D8 Venture with a PHOTON 100 CMOS area detector, using Mo-K $\alpha$ radiation $(\lambda=0.71073 \AA)$ from an Incoatec $\mathrm{I} \mu \mathrm{S}$ microsource with focusing mirrors (Table S1, ESI $\dagger$ ). Absorption corrections were carried out by empirical methods based on multiple scans and Laue equivalents (5) or numerical integration based on crystal face-indexing (6), using SADABS software. ${ }^{56}$ The structures were solved by direct (5) and Patterson (6) methods and refined by full matrix least squares using SHELXL ${ }^{57}$ and OLEX $2^{58}$ software. The unit cell of 5 contains 4 closed solventaccessible voids of $214 \AA^{3}$ each, presumably containing a disordered hexane molecule, whose contribution was removed using PLATON SQUEEZE solvent-masking procedure. ${ }^{59}$ The asymmetric unit of $\mathbf{6}$ (= half the formula unit) contains half a chlorobenzene and half a pentane molecule sharing the same void, which were refined at atomic resolution.

\section{Electrochemistry}

Cyclic voltammograms were recorded at a scan rate of $100 \mathrm{mV} \mathrm{s}^{-1}$ at room temperature using an air-tight single-compartment three-electrode cell equipped with a Pt disk working electrode, Pt wire counter electrode, and Pt wire pseudo-reference electrode. The cell was connected to a computer-controlled Autolab PG-STAT 30 potentiostat. The solutions contained the complex and $n-\mathrm{Bu}_{4} \mathrm{NPF}_{6}(0.1 \mathrm{M})$ as the supporting electrolyte in dichloromethane (DCM). All potentials were determined with the decamethylferrocene/decamethylferrocenium couple as an internal reference in DCM at $-0.55 \mathrm{~V}$ for the usual reference standard of the ferrocene/ferrocenium couple $\left(\mathrm{FcH} / \mathrm{FcH}^{+}\right)$in DCM at $0.0 \mathrm{~V}$.

\section{Photophysical measurements}

UV-Vis and photoluminescence spectra for all samples were obtained with the Shimadzu UV-3600 spectrometer and Jobin Yvon Luminescence spectrometer (FluoroMax-3). Phosphorescence decay lifetime data were measured by time-resolved emission spectroscopy (TRES) using a pulsed Nd-yttrium aluminium garnet (Nd:YAG) laser $(\lambda=355 \mathrm{~nm})$, repetition rate $1-10 \mathrm{~Hz}$, FWHM 120 ps and maximum pulse energy of $7 \mathrm{~mJ}$. The light emitted by the samples was dispersed through a spectrograph (TRIAX 180, Jobin Yvon-Spex) and the separated spectra were subsequently detected by a gated intensified charge coupled device (CCD) camera (4 pico, Stanford Computer Optics). The PL decay transients were obtained using exponentially increasing decay and integration times as previously described. ${ }^{60}$

\section{Computations}

All calculations were carried out with the Gaussian 09 package. $^{61}$ All optimised $\mathrm{S}_{0}$ geometries of 2, 4, 5 and $\mathbf{6}$ were carried out using $\mathrm{B}^{2} \mathrm{LYP}^{62}$ with the pseudopotential (LANL2DZ) ${ }^{63}$ for iridium and $3-21 G^{*}$ basis set for all other atoms. ${ }^{64}$ This model chemistry was selected on the basis of computational studies on $\operatorname{Ir}(\text { ppy })_{2} \mathrm{Cl}_{2},{ }^{17} \operatorname{Ir}(\text { ppy })_{3}{ }^{65}$ and for direct comparison with the reported data for $1 .^{34}$ All $\mathrm{S}_{0}$ geometries were found to be true minima based on no imaginary frequencies found. Electronic structure and TD-DFT calculations were also carried out on the optimised geometries at B3LYP/LANL2DZ:3-21G*. The MO diagrams and orbital contributions were generated with the aid of Gabedit ${ }^{66}$ and GaussSum ${ }^{67}$ packages, respectively. The timedependent DFT (TD-DFT) method does not include spin-orbit couplings thus no oscillation strengths for the triplet excited states are given and also does not compute mixed singlettriplet excited states (Table S8, ESI $\dagger$ ). Predicted emission data from optimised triplet excited state $\left(\mathrm{T}_{1}\right)$ geometries by TD-DFT for related iridium complexes are not reliable, ${ }^{17,62}$ thus $T_{1}$ geometries are not examined here. Given that the calculated Stokes shifts are small $\left(840-1100 \mathrm{~cm}^{-1}, 0.10-0.14 \mathrm{eV}\right.$, Table S8, ESI $\dagger$ ), it is assumed that the $\mathrm{T}_{1}$ geometries are not significantly different to their corresponding $S_{0}$ geometries in 2, 4, 5 and 6 .

\section{Device fabrication}

OLED devices were fabricated using precleaned indium tin oxide (ITO) coated glass substrate patterned to form four pixels of $4 \times 4 \mathrm{~mm}$ in $24 \times 24 \mathrm{~mm}$ samples, purchased from Kinetic. The ITO thickness was around $120 \mathrm{~nm}$ with a sheet resistance of $15 \Omega$ square $^{-1}$. The cleaned samples were exposed to UVozone for $10 \mathrm{~min}$ and purged with dry nitrogen. A hole injection layer of poly(3,4-ethylenedioxythiophene) polystyrene sulfonate (PEDOT:PSS) (4083) of thickness $40 \mathrm{~nm}$ was spin coated at $5000 \mathrm{rpm}$ for $1 \mathrm{~min}$ and then baked on a hotplate at $180{ }^{\circ} \mathrm{C}$ for $6 \mathrm{~min}$ to remove any remaining moisture. A chlorobenzene solution of $20 \mathrm{mg} \mathrm{ml}^{-1}$ of poly(9-vinylcarbazole) (PVK) of molecular weight 1000000 was both the host material and a holetransport material. The PVK solution was doped with $40 \% \mathrm{w} / \mathrm{w}$ of (1,3-phenylene)bis[5-(4-tert-butylphenyl)-1,3,4-oxadiazole] (OXD-7) 
as an electron transport material for balancing charge carrier transport.

Complexes 5 and 6 readily dissolved in chlorobenzene without any aggregated particulates. Complex 4 has low solubility which is reflected in its photophysical properties. Therefore, its device characteristics were not measured. A mixture of PVK (20 mg):OXD-7 (40 wt\%) and the complex (5 wt\%) was spincoated at $3000 \mathrm{rpm}$ for $1 \mathrm{~min}$ on the top of the PEDOT:PSS layer and baked for $10 \mathrm{~min}$ at $110{ }^{\circ} \mathrm{C}$. Each sample was shadow masked to produce four identical devices of area $4 \times 4 \mathrm{~mm}$; the samples were then introduced into a nitrogen glove box, where 2,2' $2^{\prime \prime}$-(1,3,5-benzenetriyl)tris-[1-phenyl-1 $H$-benzimidazole] (TPBi) was evaporated as an electron injection/hole blocking layer at a rate of $\sim 1 \AA^{-1}$ under vacuum at a pressure of $c a .1 \times 10^{-6}$ Torr, followed by $0.7 \mathrm{~nm} \mathrm{LiF}$ and $100 \mathrm{~nm} \mathrm{Al}$ cathodes at a rate of 0.2 and $1 \AA \mathrm{s}^{-1}$, respectively, under the same vacuum conditions. The devices were then encapsulated with DELO UV curable epoxy (Katiobond) and a $12 \times 12 \mathrm{~mm}$ glass cover slide. The final device structure was ITO/PEDOT:PSS (40 nm)/[PVK:OXD-7 (40 wt\%):Ir complex $(5 \mathrm{wt} \%)]$ TPBi $(30 \mathrm{~nm}) / \mathrm{LiF}(0.7 \mathrm{~nm}) / \mathrm{Al}(100 \mathrm{~nm})$. For devices with an additional electron blocking layer of poly[(9,9dioctylfluorenyl-2,7-diyl)-co-(4,4'-(N-(4-sec-butylphenyl)diphenylamine))] (TFB), this layer was spin-coated from toluene solution on the top of the PEDOT:PSS layer. The complex 6 (5 wt $\%$ ) and OXD-7 (40 wt\%) in PVK ( $\left.M_{\mathrm{w}} 90000\right)$ were spin coated from DMF. For all devices the current-voltage $(I-V)$ characteristics and the emission intensities were measured in a calibrated Labsphere LMS-100 integrating sphere and the data acquisition was controlled using a home-written NI LabView program that controlled an Agilent Technologies 6632B power supply. The EL spectra were measured using an Ocean Optics USB 4000 CCD spectrometer supplied with a $400 \mu \mathrm{m}$ UV-Vis fibre optic cable.

\section{Acknowledgements}

We thank EPSRC grant EP/K039423/1 for funding. The Diamond Light Source (RAL) is thanked for the award of instrument time on Station I19 (MT 11145) and the instrument scientists for their kind support. A. M. thanks the Algerian Ministry of Higher Education.

\section{References}

1 Z. Q. Chen, Z. Q. Bian and C. H. Huang, Adv. Mater., 2010, 22, 1534-1539.

2 T. You and W. Nam, Chem. Soc. Rev., 2012, 41, 7061-7084.

3 Y. Chi and P.-T. Chou, Chem. Soc. Rev., 2010, 39, 638-655.

4 M. S. Lowry and S. Bernhard, Chem. - Eur. J., 2006, 12, 7970-7977.

5 K. K. W. Lo, K. H. K. Tsang, K. S. Sze, C. K. Chung, T. K. M. Lee, K. Y. Zhang, W. K. Hui, C. K. Li, J. S. Y. Lau, D. C. M. Ng and N. Zhu, Coord. Chem. Rev., 2007, 251, 2292-2310.

6 E. Baggaley, J. A. Weinstein and J. A. G. Williams, Struct. Bonding, 2015, 165, 205-256.
7 G. Li, W. Guan, S. Du, D. Zhu, G. Shan, X. Zhu, L. Yan, Z. Su, M. R. Bryce and A. P. Monkman, Chem. Commun., 2015, 51, 16924-16927.

8 M. A. Baldo, D. F. O’Brien, Y. You, A. Shoustikov, S. Sibley, M. E. Thompson and S. R. Forrest, Nature, 1998, 395, 151-154.

9 (a) W. C. H. Choy, W. K. Chan and Y. Yuan, Adv. Mater., 2014, 26, 5368-5398; (b) L. Xiao, Z. Chen, B. Qu, J. Luo, S. Kong, Q. Gong and J. Kido, Adv. Mater., 2011, 232, 926-952; (c) X. Yang, G. Zhou and W.-Y. Wong, Chem. Soc. Rev., 2015, 44, 8484-8575; (d) W.-Y. Wong and C.-L. Ho, Coord. Chem. Rev., 2009, 253, 1709-1758; (e) C.-L. Ho, L.-C. Chi, W.-Y. Hung, W.-J. Chen, Y.-C. Lin, H. Wu, E. Mondal, G.-J. Zhou, K.-T. Wong and W.-Y. Wong, J. Mater. Chem., 2012, 22, 215-224; (f) C.-L. Ho and W.-Y. Wong, New J. Chem., 2013, 37, 1665-1683; (g) G. Zhou, W.-Y. Wong and X. Yang, Chem. - Asian J., 2011, 6, 1706-1727; (h) X. Xu, X. Yang, J. Zhao, G. Zhou and W.-Y. Wong, Asian J. Org. Chem., 2015, 4, 394-429; (i) C.-L. Ho and W.-Y. Wong, Coord. Chem. Rev., 2013, 257, 1614-1649.

10 (a) K. T. Kamtekar, A. P. Monkman and M. R. Bryce, Adv. Mater., 2010, 22, 572-582; (b) G. Zhou, W.-Y. Wong and S. Sou, J. Photochem. Photobiol., C, 2010, 11, 133-156; (c) X. Yang, G. Zhou and W.-Y. Wong, J. Mater. Chem. C, 2014, 2, 1760-1778; (d) L. Ying, C.-L. Ho, H. Wu, Y. Cao and W.-Y. Wong, Adv. Mater., 2014, 26, 2459-2473.

11 R. D. Costa, E. Ortí, H. J. Bolink, F. Monti, G. Accorsi and N. Armaroli, Angew. Chem., Int. Ed., 2012, 51, 8178-8211.

12 S. Ladouceur and E. Zysman-Colman, Eur. J. Inorg. Chem., 2013, 2985-3007.

13 M. Nonoyama, Bull. Chem. Soc. Jpn., 1974, 47, 767-768.

14 A. B. Tamayo, B. D. Alleyne, P. I. Djurovich, S. Lamansky, I. Tsyba, N. N. Ho, R. Bau and M. R. Thompson, J. Am. Chem. Soc., 2003, 125, 7377-7387.

15 G. A. Carlson, P. I. Djurovich and R. J. Watts, Inorg. Chem., 1993, 32, 4483-4484.

16 S. Bettington, M. Tavasli, M. R. Bryce, A. S. Batsanov, A. L. Thompson, H. A. Al Attar, F. B. Dias and A. P. Monkman, J. Mater. Chem., 2006, 16, 1046-1052.

17 A. M'hamedi, A. S. Batsanov, M. A. Fox, M. R. Bryce, K. Abdullah, H. A. Al-Attar and A. P. Monkman, J. Mater. Chem., 2012, 22, 13529-13540.

18 M. Y. Wong, G. Xie, C. Tourbillon, M. Sandroni, D. B. Cordes, A. M. Z. Slawin, I. D. W. Samuel and E. Zysman-Colman, Dalton Trans., 2015, 44, 8419-8432.

19 X. Yuan, S. Zhang and Y. Ding, Inorg. Chem. Commun., 2012, 17, 26-29.

20 A. Tsuboyama, T. Takiguchi, S. Okada, M. Osawa, M. Hoshino and K. Ueno, Dalton Trans., 2004, 1115-1116.

21 E. A. Plummer, W. Hofstraat and L. De Cola, Dalton Trans., 2003, 2080-2084.

22 L. Donato, C. E. McCusker, F. N. Castellano and E. Zysman-Colman, Inorg. Chem., 2013, 52, 8495-8504.

23 E. S. Andreiadis, D. Imbert, J. Pécaut, A. Calborean, I. Ciofini, C. Adamo, R. Demadrille and M. Mazzanti, Inorg. Chem., 2011, 50, 8197-8206. 
24 J. Fernández-Cestau, N. Giménez, E. Lalinde, P. Montaño, M. T. Moreno and S. Sánchez, Organometallics, 2015, 34, 1766-1778.

25 F. M. Hwang, H. Y. Chen, P. S. Chen, C. S. Liu, Y. Chi, C. F. Shu, F. I. Wu, P. T. Chou, S. M. Peng and G. H. Lee, Inorg. Chem., 2005, 44, 1344-1353.

26 T. Hajra, J. K. Bera and V. Chandrasekhar, Aust. J. Chem., 2011, 64, 561-566.

27 A. M. Prokhorov, A. Santoro, J. A. G. Williams and D. W. Bruce, Angew. Chem., Int. Ed., 2012, 51, 95-98.

28 G. Li, Y. Wu, G. Shan, W. Che, D. Zhu, B. Song, L. Yan, Z. Su and M. R. Bryce, Chem. Commun., 2014, 50, 6977-6980.

29 P.-H. Lanoë, C. M. Tong, R. W. Harrington, M. R. Probert, W. Clegg, J. A. G. Williams and V. N. Kozhevnikov, Chem. Commun., 2014, 50, 6831-6834.

30 M. Graf, K. Sünkel, R. Czerwieniec and H.-C. Böttcher, J. Organomet. Chem., 2013, 745-746, 341-346.

31 V. Chandrasekhar, T. Hajra, J. K. Bera, S. M. W. Rahaman, N. Satumtira, O. Elbjeirami and M. A. Omary, Inorg. Chem., 2012, 51, 1319-1329.

32 M. Graf, R. Czerwieniec and K. Sünkel, Z. Anorg. Allg. Chem., 2013, 639, 1090-1094.

33 R. E. Daniels, S. Culham, M. Hunter, M. C. Durrant, R. M. Probert, W. Clegg, J. A. G. Williams and V. N. Kozhevnikov, Dalton Trans., 2016, 45, 6949-6962.

34 Y. Zheng, A. S. Batsanov, M. A. Fox, H. A. Al-Attar, K. Abdullah, V. Jankus, M. R. Bryce and A. P. Monkman, Angew. Chem., Int. Ed., 2014, 53, 11616-11619.

35 X. Yang, X. Xu, J. Dang, G. Zhou, C.-L. Ho and W.-Y. Wong, Inorg. Chem., 2016, 55, 1720-1727.

36 (a) M. Y. Wong, G. Xie, C. Tourbillon, M. Sandroni, D. B. Cordes, A. M. Z. Slawin, I. D. W. Samuel and E. Zysman-Colman, Dalton Trans., 2015, 44, 8419-8432; (b) K. He, X. Wang, J. Yu, H. Jiang, G. Xie, H. Tan, Y. Liu, D. Ma, Y. Wang and W. Zhu, Org. Electrochem., 2014, 15, 2942-2949.

37 G. Nasr, A. Guerlin, F. Dumur, L. Beouch, E. Dumas, G. Clavier, F. Miomandre, F. Goubard, D. Gigmes, D. Bertin, G. Wantz and C. R. Mayer, Chem. Commun., 2011, 47, 10698-10700.

38 V. N. Kozhevnikov, Y. Zheng, M. Clough, H. A. Al-Attar, G. C. Griffiths, K. Abdullah, S. Raisys, V. Jankus, M. R. Bryce and A. P. Monkman, Chem. Mater., 2013, 25, 2352-2358.

39 A. F. Henwood, A. K. Bansal, D. B. Cordes, A. M. Z. Slawin, I. D. W. Samuel and E. Zysman-Colman, J. Mater. Chem. C, 2016, 4, 3726-3737.

40 D. Rota Martir, A. K. Bansal, V. Di Mascio, D. B. Cordes, A. F. Henwood, A. M. Z. Slawin, P. C. J. Kamer, L. MartinezSarti, A. Pertegas, H. J. Bolink, I. D. W. Samuel and E. Zysman-Colman, Inorg. Chem. Front., 2016, 3, 218-235.

41 H. Benjamin, Y. Zheng, A. S. Batsanov, M. A. Fox, H. A. Al-Attar, A. P. Monkman and M. R. Bryce, Inorg. Chem., 2016, 55, 8612-8627.

42 D. Rota Martir, G. J. Hedley, D. B. Cordes, A. M. Z. Slawin, D. Escudero, D. Jacquemin, T. Kosikova, D. Philip, D. M. Dawson, S. E. Ashbrook, I. D. W. Samuel and E. ZysmanColman, Dalton Trans., 2016, 45, 17195-17205.
43 D. Rota Martir, C. Momblona, A. Pertegás, D. B. Cordes, A. M. Z. Slawin, H. J. Bolink and E. Zysman-Colman, ACS Appl. Mater. Interfaces, 2016, 8, 33907-33915.

44 S. Sprouse, K. A. King, P. J. Spellane and R. J. Watts, J. Am. Chem. Soc., 1984, 105, 6647-6653.

45 A. Auffrant, A. Barbieri, F. Barigelletti, J. Lacour, P. Mobian, J.-P. Collin, J.-P. Sauvage and B. Ventura, Inorg. Chem., 2007, 46, 6911-6919.

46 S. Lamansky, P. Djurovich, D. Murphy, F. Abdel-Razzaq, C. Adachi, P. E. Burrows, S. Forrest and M. E. Thompson, J. Am. Chem. Soc., 2001, 123, 4304-4312.

47 P. J. Hay, J. Phys. Chem. A, 2002, 106, 1634-1641.

48 W. J. Finkenzeller and H. Yersin, Chem. Phys. Lett., 2003, 377, 299-305.

49 T. Sajoto, P. I. Djurovich, A. B. Tamayo, J. Oxgaard, W. A. Goddard III and M. E. Thompson, J. Am. Chem. Soc., 2009, 131, 9813-9822.

50 (a) J.-H. Jou, W.-B. Wang, S.-M. Shen, S. Kumar, I.-M. Lai, J.-J. Shyue, S. Lengvinaite, R. Zostautiene, J. V. Grazulevicius, S. Grigalevicius, S.-Z. Chen and C.-C. Wu, J. Mater. Chem., 2011, 21, 9546-9552; (b) M. Song, J. S. Park, Y.-S. Gal, S. Kang, J. Y. Lee, J. W. Lee and S.-H. Jin, J. Phys. Chem. C, 2012, 116, 7526-7533.

51 (a) H. A. Al-Attar and A. P. Monkman, J. Appl. Phys., 2011, 109, 074516; (b) F. Dumur, Org. Electrochem., 2015, 25, 345-361.

52 R. Jin, P. A. Levermore, J. Huang, X. Wang, D. D. C. Bradley and J. C. deMello, Phys. Chem. Chem. Phys., 2009, 11, 3455-3462.

53 J.-W. Jou, S. Kumar, A. Agrawal, T.-H. Li and S. Sahoo, J. Mater. Chem. C, 2015, 3, 2974-3002.

54 A. C. Arias, J. D. MacKenzie, I. McCulloch, J. Rivnay and A. Salleo, Chem. Rev., 2010, 110, 3-24.

55 I. Welterlich, O. Charov and B. Tieke, Macromolecules, 2012, 45, 4511-4519.

56 G. M. Sheldrick, SADABS version 2014/5, Bruker AXS, Madison, USA.

57 (a) G. M. Sheldrick, Acta Crystallogr., 2008, A64, 112-122; (b) G. M. Sheldrick, Acta Crystallogr., 2015, C71, 3-8.

58 O. V. Dolomanov, L. J. Bourhis, R. J. Gildea, J. A. K. Howard and H. Puschmann, J. Appl. Crystallogr., 2009, 42, 339-341.

59 A. L. Spek, J. Appl. Crystallogr., 2003, 36, 7-13.

60 C. Rothe and A. P. Monkman, Phys. Rev. B: Condens. Matter Mater. Phys., 2003, 68, 075208.

61 M. J. Frisch, G. W. Trucks, H. B. Schlegel, G. E. Scuseria, M. A. Robb, J. R. Cheeseman, G. Scalmani, V. Barone, B. Mennucci, G. A. Petersson, H. Nakatsuji, M. Caricato, X. Li, H. P. Hratchian, A. F. Izmaylov, J. Bloino, G. Zheng, J. L. Sonnenberg, M. Hada, M. Ehara, K. Toyota, R. Fukuda, J. Hasegawa, M. Ishida, T. Nakajima, Y. Honda, O. Kitao, H. Nakai, T. Vreven, J. A. Montgomery, Jr., J. E. Peralta, F. Ogliaro, M. Bearpark, J. J. Heyd, E. Brothers, K. N. Kudin, V. N. Staroverov, R. Kobayashi, J. Normand, K. Raghavachari, A. Rendell, J. C. Burant, S. S. Iyengar, J. Tomasi, M. Cossi, N. Rega, J. M. Millam, M. Klene, J. E. Knox, J. B. Cross, V. Bakken, C. Adamo, J. Jaramillo, R. Gomperts, R. E. Stratmann, O. Yazyev, A. J. Austin, R. Cammi, C. Pomelli, 
J. W. Ochterski, R. L. Martin, K. Morokuma, V. G. Zakrzewski, G. A. Voth, P. Salvador, J. J. Dannenberg, S. Dapprich, A. D. Daniels, O. Farkas, J. B. Foresman, J. V. Ortiz, J. Cioslowski and D. J. Fox, Gaussian 09, Revision A.02, Gaussian, Inc., Wallingford CT, 2009.

62 (a) A. D. Becke, J. Chem. Phys., 1993, 98, 5648-5652; (b) C. Lee, W. Yang and R. G. Parr, Phys. Rev. B: Condens. Matter Mater. Phys., 1988, 37, 785-789.

63 (a) T. H. Dunning, Jr and P. J. Hay in Modern Theoretical Chemistry, ed. H. F. Schaefer III, Plenum, New York, vol. 3, 1976; (b) P. J. Hay and W. R. Wadt, J. Chem. Phys., 1985, 82, 270-283; (c) W. R. Wadt and P. J. Hay, J. Chem. Phys., 1985,
82, 284-298; (d) P. J. Hay and W. R. Wadt, J. Chem. Phys., 1985, 82, 299-310.

64 (a) G. A. Petersson and M. A. Al-Laham, J. Chem. Phys., 1991, 94, 6081-6090; (b) G. A. Petersson, A. Bennett, T. G. Tensfeldt, M. A. Al-Laham, W. A. Shirley and J. Mantzaris, J. Chem. Phys., 1988, 89, 2193-2218.

65 M. Tavasli, T. N. Moore, Y. Zheng, M. R. Bryce, M. A. Fox, G. C. Griffiths, V. Jankus, H. A. Al-Attar and A. P. Monkman, J. Mater. Chem., 2012, 22, 6419-6428.

66 A. R. Allouche, J. Comput. Chem., 2011, 32, 174-182.

67 N. M. O'Boyle, A. L. Tenderholt and K. M. Langner, J. Comput. Chem., 2008, 29, 839-845. 